IZA DP No. 2901

Why Is Child Labor Illegal?

Sylvain Dessy

J ohn Knowles

J uly 2007 


\title{
Why Is Child Labor Illegal?
}

\author{
Sylvain Dessy
}

Université Laval

John Knowles

University of Pennsylvania

and IZA

\section{Discussion Paper No. 2901 \\ July 2007}

\author{
IZA \\ P.O. Box 7240 \\ 53072 Bonn \\ Germany \\ Phone: +49-228-3894-0 \\ Fax: +49-228-3894-180 \\ E-mail: iza@iza.org
}

Any opinions expressed here are those of the author(s) and not those of the institute. Research disseminated by IZA may include views on policy, but the institute itself takes no institutional policy positions.

The Institute for the Study of Labor (IZA) in Bonn is a local and virtual international research center and a place of communication between science, politics and business. IZA is an independent nonprofit company supported by Deutsche Post World Net. The center is associated with the University of Bonn and offers a stimulating research environment through its research networks, research support, and visitors and doctoral programs. IZA engages in (i) original and internationally competitive research in all fields of labor economics, (ii) development of policy concepts, and (iii) dissemination of research results and concepts to the interested public.

IZA Discussion Papers often represent preliminary work and are circulated to encourage discussion. Citation of such a paper should account for its provisional character. A revised version may be available directly from the author. 


\section{ABSTRACT}

\section{Why Is Child Labor Illegal?*}

We present a theory of the emergence of laws restricting child labor or imposing mandatory education that is consistent with the fact that poor parents tend to oppose such laws. We find that if altruistic parents are unable to commit to educating their children, child-labor laws can increase the welfare of higher-income parents in an ex ante sense. On the basis of an empirical analysis of Latin-American household surveys, we demonstrate that per capita income in the country of residence has the predicted effect on child labor supply, even after controlling for other household characteristics.

JEL Classification: J82, O11

Keywords: macroeconomic analyses of economic development, labor force composition

Corresponding author:

John Knowles

Deptartment of Economics

University of Pennsylvania

3718 Locust Walk

Philadelphia, PA 19104

USA

E-mail: jknowles@econ.sas.upenn.edu

\footnotetext{
* The authors thank Miguel Szekely and Alejandro Gaviria of the InterAmerican Development Bank, as well as the statistical agencies of Argentina, Bolivia, Brasil, Chile, Colombia, Costa Rica, Ecuador, Mexico, Panama, Paraguay, Peru and Venezuela for access to household survey data. We are also grateful to Bernard Fortin, and Steven Gordon for helpful discussions, and to seminar participants at the NBER Summer Institute 2000, SED 2000, and ITAM's "Consequences of Financial Crises" conference, Summer 2000. Knowles is grateful for financial support from the National Science Foundation.
} 


\section{Introduction}

Why do countries enact child-labor laws or enforce mandatory full-time education of children? Until a little more than 150 years ago, poor children in most countries spent their days in labor, rather than education. This was the rule even in rich countries, including the US and Great Britain. Today, most countries have child-labor laws and are imposing education as the normal occupation of a child regardless of his/her family's economic background. However, if we believe that parents are altruistic towards their children, then it is difficult to explain why compulsory education laws would make people better off. ${ }^{1}$ According to current economic theories of the household, as in Becker (1976) and Rosenzweig and Evenson (1977), altruistic parents only send their children to work when this enhances the welfare of the family, so legislation mandating compulsory education can only reduce the welfare of households, particularly those so poor that children's income is essential for survival. ${ }^{2}$

Under standard assumptions, the simplest explanation of the above observations is that compulsory education laws are not binding; they merely formalize the optimal decisions of households in countries that have become so rich over time that even the poorest parents want to educate their children. In Figure 1 in the appendix section, we present the results of a regression for 54 countries for which the UN has reported positive child-labor rates: we see that child labor around the world is negatively related to GDP per capita. In fact, variation in GDP explains $68 \%$ of the variance in child-labor rates among these countries. So it is quite plausible that this simple explanation is correct; child-labor rates have declined

\footnotetext{
${ }^{1}$ We take compulsory education and child-labor restrictions to be equivalent. Indeed, Weiner (1991) finds the two to be highly correlated over time. Both Weiner (1991) and Fyfe (2005) find the two types of laws are best described as complementary aspects of the same policy.

${ }^{2}$ Grootaert and Kanbur (1995) show that only after the incidence of child labor had already begun to decline, in 1833, a time when $36.6 \%$ of boys aged 10-14 were working, did Britain pass legislation restricting child labor. This, as well as the observation by Goldin (1979) that higher wages for fathers in Philadelphia in the late 19th century reduced the probability of child labor, suggest that the forces driving child labor in poor countries today are fundamentally similar to those experienced by the US and England in the 19th century.
} 
spontaneously over time simply because rising prosperity has made children's education optimal for all families. If so, then compulsory education laws are only useful to aid parents in achieving the optimal decisions they would have made freely, perhaps by protecting children from exploitative or coercive transactions. If this is the case, we should not expect to see much popular concern over such laws, and compliance should not be an issue.

In fact there is plentiful evidence that poor parents vociferously opposed such laws, and that enforcement is difficult and costly. According to a report released by the Bureau of International Labor Affairs of the US Department of Labor (1998), the advent of compulsory education in Latin America was met with strong opposition from poor families, forcing many Latin American governments to design and implement a number of redistribution mechanisms aimed at compensating poor families for the loss of income that results when children go to school instead of working. A number of mechanisms have been used for over ten years, including free school meals, supplies, health care, and clothing, access to microcredit, and education vouchers, and even cash stipends. The result in Latin American countries has been a dramatic increase in primary school enrolment, attendance, as well as an increase in the rate of pupils' retention, as in Todd and Wolpin (2006) and Behrman, Todd, and Sengupta (2005), who report results for the PROGRESA program in Mexico, which provides cash conditional on students attending school and visiting health clinics. Similarly, Fyfe (2005) finds that opposition to mandatory education in Brazil was strongest in the poorest states, and that, as in Mexico, raising compliance required "conditional cash transfer" programs.

If mandatory-education laws actually prevent parents from making their preferred decisions with respect to their children's education or employment, then why are they enacted? Recent research appeals to externalities in the labor market, or in education, and argues that while restricting a parent's choice may make the family worse off, the parent gain from the restriction on other families. For example, Doepke and Zilibotti (2005) offer a theory of the emergence of child labor restrictions in which both the pressure to impose child labor restrictions (CLRs) and the resistance to such pressure come primarily from within the 
unskilled labor union movement, the result of conflict between workers with and without children. Because their model naturally leads to a multiplicity of equilibria, it implies that restricting child labor can be equally beneficial for richer and poorer countries. Eckstein and Zilcha (1994),Basu (1999), Baland and Robinson (2000), and Doepke and Krueger (2006)).

While such mechanisms are also plausible, the empirical implications for laws restricting children's labor are not clear; poor countries would seem to benefit equally from restricting children's participation in the labor market, so an explanation of the tolerance of child labor in these countries is lacking. None of these views, moreover, consider the possibility that such restrictive laws may be the outcome of a conflict between the interests of poor and middle-class families. By reducing the income of families at subsistence level, laws restricting child labor or imposing mandatory education make such families worse off, even while making higher-income families better off. When such laws were adopted in the U.S., Kleinberg (2005) finds that, political campaigns for the imposition of compulsory education were led by the middle class, with opposition from the working-class.

This paper proposes a theory of political conflict over mandatory education based on the fact that there is a long delay between the costs and the returns of investing in education. For households close to subsistence level, the cost of education is the foregone income the child could have provided by working; thus education implies a concurrent reduction in consumption. The rewards come much later in life, when the child is earning a higher income as an adult. in that sense, our model is similar to the standard altruistic model, as in Loury (1981). However in our theory of child labor, parents are more impatient between today and tomorrow than they are between adjacent periods further in the future, as in the large literature on 'hyperbolic discounting' pioneered by Strotz (1955). Faced with the trade-off between education of their children and household income from child labor, poor parents may choose less education for their child than they would were they able to commit to an education path at the time the child reaches school age.

In the absence of other institutions allowing parents to commit to an education plan, compulsory education laws may increase the welfare of poor households in an ex ante sense 
by allowing parents to achieve a higher level of education for their children than they would be able to achieve with an unconstrained choice set. Indeed, based upon psychological experiments, Mullainathan (2006) argues that parents' self-control problems act as a barrier to children's education. Furthermore, recent research in the retirement-savings literature, such as Laibson, Repetto, and Tobacman (1998) and Laibson (1997), suggests that people are likely to under invest, relative to their preferences ex ante, when rewards are deferred to the end of the lifecycle, as is the case for child education. ${ }^{3}$ Another application of this argument to social policy is Fang and Silverman (2000), who examine justification for work requirements in U.S. welfare programs.

Our theory explicitly incorporates competing roles for income and the rate of return to education as explanations of the country effect on child labor, and implicitly allows a role for other country characteristics that affect the age at which compulsory schooling laws are binding. The assumptions of our model imply that only when parents have wage levels in an intermediate interval will compulsory education laws make them better off; low-wage parents are worse off and high-wage parents are indifferent. This suggests a simple theory of the emergence of mandatory-education laws in which a country is composed of parents who differ by their education and hence skill levels. Initially, most parents are too poor to even desire a full-time education for their child. Over time, skill levels and hence parental wages may increase; at the moment when a critical mass of parents enter the wage interval defined above, a majority of the adult population would favor legislation compelling full-time education of all children, or other restrictions on child labor.

If, in order to be successfully enforced, compulsory education laws must win political support from a large enough coalition, then our theory provides a threshold condition which poor countries must pass for compulsory education laws to be enacted. Our theory also suggests that a ban by rich countries on imports of child labor can make households in poor

\footnotetext{
${ }^{3}$ In the public policy arena self-control problems affecting parental investment in child's schooling are increasingly recognized. Examples include, but are not restricted to, the government of Canada's Education Savings Grant Program (CESG), the State of Kentucky's Education Savings Plan Trust, and the State of Utah's Higher Education Savings Program.
} 
countries better off and raise education levels of their children, but only at the expense of children in even poorer households.

We begin by presenting a general formulation of the model. In Section 3 explore welfare implications of an exogenous reduction in child wages. In section 4 we solve a parametric example. Section 5 contains an empirical analysis of the degree to which country of residence affects child labor rates, and the extent to which such measures of a country's permissiveness towards child labor are correlated with GDP and other aggregates.

\section{A Model of Child Labor}

In this section we present a simple theory of parental decisions regarding the allocation of children's time between labor and education. Under our assumptions, parents may favor child-education laws because they help parents to commit to more education for the child. The key assumptions are: 1) child labor reduces education, 2) parents get utility from the education of their children, and 3) parent's discount factors for future utility are quasigeometric. The main result of the model is that parents support laws that restrict children to a minimum time spent in school as a commitment device for adequately investing in their children's education.

Consider an economy where agents live for $2 T+1$ periods, the first $T$ as children, and then $T+1$ periods as parents, with one child born when the parent is aged $T$. The parent has an endowment of human capital $h_{p}$ and receives labor income $w h_{p}$. Children may become workers from the time that the parent is aged $T+1$. Their human capital on attaining adulthood at period $T$ is given by $h_{T}^{c}$, which depends on the fraction $e_{t}^{c}$ of their time they have allocated to their education at each age. This allocation is decided by the parent. The child's initial human capital is $h_{0}^{c}$, and evolves deterministically according to the function:

$$
h_{t+1}^{c}=\phi\left(h_{t}^{c}, e_{t}^{c}\right) .
$$

Parents get utility $u\left(c_{\tau}\right)$ from their own consumption in each period $\tau$ of their own finite lives and utility $\nu\left(h_{T}^{c}\right)$ in the final period of life from the final level $h_{T}^{c}$ of their children's 
education. Parent's discount factors for future utility are quasi-geometric; the discount factor between adjacent future periods is $\beta \in(0,1)$, but between the present and the immediate future, the discount factor is $\beta \delta \in(0, \beta)$. Preferences take the following time-separable form:

$$
U_{0}=u\left(c_{0}\right)+\delta\left[\beta^{T} \nu\left(h_{T}^{c}\right)+\sum_{\tau=1}^{T} \beta^{\tau} u\left(c_{\tau}\right)\right]
$$

Children's labor income depends on the fraction of time $\left(1-e_{t}^{c}\right)$ the child works in period $t$, and on the child's effective wage $w_{t}^{c}$, which is the basic child's wage $w_{1}^{c}$, times the child's productivity premium for age. The child's wage is not a function of the child's human capital. ${ }^{4}$ Furthermore, following Cain (1977), it is assumed that a child aged $t+1$ is the productive equivalent of $\left(1+\gamma_{t}\right)$ children aged $t$. Therefore a child aged $t+1$ will face an effective wage rate

$$
w_{t+1}^{c}=\left(1+\gamma_{t}\right) w_{t}^{c}, \quad 0 \leq \gamma_{t}<1
$$

all $t$. As the child grows older, the productivity premium for age, $\gamma_{t}$, declines, as the child's wage converges toward the adult wage. A direct implication is that the sequence of agespecific productivity differentials $\left\{\gamma_{t}\right\}_{t=1}^{T}$ converges from above towards zero as $t$ approaches $T$.

In each period $t \leq T$, parental consumption is constrained by the total household labor income, which is equal to the sum of parental labor income and that of the child. Let $p_{t}$ denotes the period- $t$ per unit education cost reflecting for example, expenditures on school supplies, registration fees, transportation costs etc. Then the parent period- $t$ budget constraint is given by:

$$
c_{t} \leq w_{p} h_{p}+\left(1-e_{t}^{c}\right) w_{t}^{c}-p_{t} e_{t}
$$

This parental budget constraint implies that, in addition to the direct cost, $p_{t} e_{t}$, of educating a child, there is also an indirect cost, in the form of household income foregone from child labor sources $w_{t}^{c} e_{t}^{c}$. The essential point, that child labor significantly reduces both

\footnotetext{
${ }^{4}$ This assumption is standard in the literature on child labor; see Glomm (1997); Baland and Robinson (2000); or Dessy (2000).
} 
educational time and eventual attainment, is well supported by empirical studies, such as Rosenzweig and Evenson (1977) and Psacharopoulos (1997).

In their first period, children are physically incapable of working, so parental consumption equals $w_{p} h_{p}$. Since parents make no time-allocation decisions this period, when their child has age $t=1$, it will be ignored below, except to consider parental support over labor laws.

It will be assumed below that the above functions obey the following standard conditions:

U.1 $u^{\prime}>0 ; u^{\prime \prime}<0 ; u^{\prime}(c) \rightarrow \infty \quad$ as $c \rightarrow 0 ; u^{\prime}(c) \rightarrow 0$ as $c \rightarrow \infty$.

U.2 $v^{\prime}>0 ; v^{\prime \prime}<0 ; v^{\prime}(h) \rightarrow \infty \quad$ as $h \rightarrow 0 ; v^{\prime}(h) \rightarrow 0$ as $h \rightarrow \infty$.

U.3 $\phi_{e}>0, \phi_{h}>0, \phi_{e e}<0, \phi_{h h}<0, \phi_{e, h}>0$.

Assumption 3 implies that education time and previous attainment are complements in the production of next period's attainment. Furthermore the second-derivative assumptions imply enough concavity that interior solutions, when they exist, are optimal.

\subsection{Optimal Education Decisions}

In general the choice of education at time $T-j$ will deviate for two reasons from the choice of a parent who can commit at $t=0$. First is the direct effect of impatience, i.e. the change in discount factor between $T-j$ and $T-j+1$. Second, there may be strategic interaction between the parent's decisions at different time periods. These effects are illustrated below.

It is straight-forward to solve the parent's problem by backwards induction. In the last period of life, the parent's payoff is given by $\nu\left(\phi\left(h_{T-1}^{c}, e_{T-1}^{c}\right)\right)$. Therefore when allocating the child's time between education and labor in the penultimate period, the parent faces the following dynamic programming problem:

$$
V_{T-1}^{0}\left(h_{T-1}^{c}, h_{p}\right)=\max _{e_{T-1}^{c}}\left\{u\left[w_{p} h_{p}+\left(1-e_{T-1}^{c}\right) w_{T-1}^{c}-e_{T-1}^{c} p_{T-1}\right]+\beta \delta \nu\left(\phi\left(h_{T-1}^{c}, e_{T-1}^{c}\right)\right)\right\}
$$

, subject to (2.2) and (2.1).

An interior solution satisfies the following first-order condition:

$$
\left[w_{T-1}^{c}+p_{T-1}\right] u^{\prime}\left(c_{T-1}\right)=\beta \delta \nu^{\prime}\left(h_{T}^{c}\right) \phi_{e}\left(h_{T-1}^{c}, e_{T-1}^{c}\right)
$$


. Diminishing marginal utility implies that if the optimal $e_{T-1}^{c}$ is interior, then the child's education will be increasing in the parent's human capital, $h_{p}$. Furthermore, the presence of $\delta$ on the right hand side implies that the education choice, if interior, will be strictly less than what the parent would have chosen could he have committed to $e_{T-1}^{c}$ at some earlier time.

Given the above assumptions, it is important to ask whether parents whose children have a higher level of human capital carried over from the preceding period will tend to invest less in their children at time $T-1$. In other words, we look for the effect an increase in $h_{T-1}^{c}$ has on the optimal $e_{T-1}^{c}$. As shown in the following proposition, the answer to this question depends upon whether a marginal increase in the level of human capital carried over from the previous periods "sufficiently" raises the marginal productivity of child's time allocated to education:

Proposition 1. Let assumptions U.1 - U.3 hold. If

$$
\phi_{e h}<\frac{-\nu^{\prime \prime}}{\nu^{\prime}} \phi_{e} \phi_{h}
$$

then, $\partial e_{T-1} / \partial h_{T-1}^{c}<0$. Furthermore, we have that (ii) $\partial e_{T-1} / \partial h_{p}>0$, and (iii) $\partial e_{T-1} / \partial \delta>$ 0 , where $e_{T-1}=g_{T-1}\left(\delta, h_{p}, h_{T-1}^{c}\right)$ denotes the interior solution to (2.3).

$\mathbf{P}$ roof. Given the properties of the functions $u, \nu$, and $\phi$, the second order condition for a maximum is satisfied: $\left[w_{T-1}^{c}+p_{T-1}\right]^{2} u^{\prime \prime}+\beta \delta\left[\nu^{\prime \prime} \phi_{e}^{2}+\nu^{\prime} \phi_{e e}\right]<0$. The implicit function theorem may then be applied to establish all three results.

Condition (2.4) states that the increase in the productivity of time allocated to schooling due to a marginal increase in the level of human capital carried over from the previous periods is not "too" large. The property $\partial e_{T-1} / \partial h_{T-1}^{c}<0$ of the optimal education policy function means that child's time allocated to education tends to be smaller(greater), the higher (smaller) the child's human capital level carried over from the previous period. Property $\partial e_{T-1} / \partial h_{p}>0$ states that richer parents tend to invest more on their children's education. Finally, property $\partial e_{T-1} / \partial \delta>0$ states that child's time allocated to schooling declines with the severity of the time-inconsistency (or commitment) problem.

To define the solutions for the preceding periods, it is convenient to analyze the parental 
decision as the outcome of a 2-stage dynamic-programming problem, as in Krusell and Smith (2003). Using the definition of the optimal education policy, the resulting children's human capital is given by:

$$
h_{t+1}^{c}=\phi\left[h_{t}^{c}, g_{t}\left(\delta, h_{p}, h_{t}^{c}\right)\right]
$$

At time $T-2$, the parental problem is to maximize:

$$
V_{T-2}^{0}\left(h_{T-2}^{c}, h_{p}\right)=\max _{e_{T-2}^{c}}\left\{u\left[w_{p} h_{p}+\left(1-e_{T-2}^{c}\right) w_{T-2}^{c}-e_{T-2}^{c} p_{T-2}\right]+\beta \delta W_{T-1}^{0}\left(h_{T-1}^{c}, h_{p}\right)\right\}
$$

subject to

$$
\begin{aligned}
W_{T-1}^{0}\left(h_{T-1}^{c}, h_{p}\right)= & u\left[w_{p} h_{p}+\left(1-g\left(h_{T-1}^{c} ; h_{p}\right)\right) w_{T-1}^{c}-g\left(h_{T-1}^{c} ; h_{p}\right) p_{T-1}\right] \\
& +\beta\left[\nu\left(\phi\left[h_{T-1}^{c}, g\left(h_{T-1}^{c} ; h_{p}\right)\right]\right)\right]
\end{aligned}
$$

and $h_{T-1}^{c}=\phi\left[h_{T-2}^{c}, e_{T-2}^{c}\right]$, where $(2.9)$ denotes the continuation value at $T-1$.

$>$ From the point of view of period $T-2$, the discount factor between periods $T-1$ and $T$ is given by $\beta$, but the parent knows that when the time comes to choose $e_{T-1}^{c}$, the discount factor between periods $T-1$ and $T$ will be $\beta \delta$.

The first-order condition at time $T-2$ is:

$$
-\left[w_{T-2}^{c}+p_{T-2}\right] u^{\prime}\left(c_{T-2}\right)+\beta \delta \frac{\partial W_{T-1}^{0}\left(h_{T-1}^{c}, h_{p}\right)}{\partial h_{T-1}^{c}} \phi_{e}\left(h_{T-2}^{1}, e_{T-2}^{c}\right)=0 .
$$

This first order condition is satisfied by the education time $e$ that equates the marginal cost of educating the child at $T-2$ to the marginal (future) utility from raising the child's human capital level. Given that the parent will act impatiently in the future, at $T-2$ she perceives the marginal benefit of education as:

$$
\begin{aligned}
\frac{\partial W_{T-1}^{0}\left(h_{T-1}^{c}, h_{p}\right)}{\partial h_{T-1}^{c}}= & \frac{\partial g_{T-1}}{\partial h_{T-1}^{c}} \cdot\left[-\left[w_{T-1}^{c}+p_{T-1}\right] u^{\prime}\left(c_{T-1}\right)+\beta \nu^{\prime}\left(h_{T}^{1}\right) \phi_{e}\left(h_{T-1}^{c}, g_{T-1}\right)\right] \\
& +\beta \nu^{\prime}\left(h_{T}^{1}\right) \phi_{h}\left(h_{T-1}^{c}, g_{T-1}\right)
\end{aligned}
$$

where $g_{T-1} \equiv g_{T-1}\left(\delta, h_{T-1}^{c}, h_{p}\right)$. 
The second term on the right hand side is perfectly standard; the first term however only appears due to the time-inconsistency of the parental preferences; otherwise the envelope theorem tells us that the term multiplying the policy function derivative would be zero at the optimum, in which case

$$
\frac{\partial W_{T-1}^{0}\left(h_{T-1}^{c}, h_{p}\right)}{\partial h_{T-1}^{c}}=\beta \nu^{\prime}\left(h_{T}^{1}\right) \phi_{h}\left(h_{T-1}^{c}, g_{T-1}\right)
$$

. However without commitment, it becomes important to investigate whether the marginal benefit of an additional increment in the child's level of human capital carried over from the preceding period (i.e., the term $\left.\partial W_{T-1}^{0}\left(h_{T-1}^{c}, h_{p}\right) / \partial h_{T-1}^{c}\right)$ turns out to be larger or smaller than the level that would obtain under commitment (i.e., the term $\left.\beta \nu^{\prime}\left(h_{T}^{1}\right) \phi_{h}\left(h_{T-1}^{c}, g_{T-1}\right)\right)$. The answer to this question is summarized by the following proposition.

Proposition 2. Let condition (2.4) hold. Then

$$
\frac{\partial W_{T-1}^{0}\left(h_{T-1}^{c}, h_{p}\right)}{\partial h_{T-1}^{c}}<\beta \nu^{\prime}\left(h_{T}^{1}\right) \phi_{h}\left(h_{T-1}^{c}, g_{T-1}\right) .
$$

$\mathbf{P}$ roof. Since condition (2.4) hold, by proposition 1, $\partial g_{T-1} / \partial h_{T-1}^{c}<0$. Furthermore, since by proposition $1 \partial g_{T-1} / \partial \delta>0$ and $u^{\prime \prime}<0$, then

$$
-\left[w_{T-1}^{c}+p_{T-1}\right] u^{\prime}\left[w_{p} h_{p}+\left(1-g_{T-1}\right) w_{T-1}^{c}-g_{T-1} p_{T-1}\right]+\beta \nu^{\prime}\left(h_{T}^{1}\right) \phi_{e^{c}}\left(h_{T-1}^{c}, g_{T-1}\right)>0,
$$

implying that the policy $g_{T-1}\left(\delta, h_{T-1}^{c}, h_{p}\right)$ is sub-optimal from the point of view of period $T-2$. Hence the result.

Proposition 2 states that both the direct and strategic effects of time inconsistency reduce the perceived future benefits of educating the child at $T-2$. This in turn causes parents to choose inefficient levels of child's schooling time in each period.

Earlier stages of the game are solved by applying the same approach. At time $T-3$, the parental problem is to maximize:

$$
V_{T-3}^{0}\left(h_{T-3}^{c}, h_{p}\right)=\max _{e_{T-3}^{c}}\left\{u\left[w_{p} h_{p}+w_{T-3}^{c}-e_{T-3}^{c}\left(w_{T-3}^{c}+p_{T-3}\right)\right]+\beta \delta W_{T-2}^{0}\left(h_{T-2}^{c}, h_{p}\right)\right\}
$$

subject to the continuation value from the period $T-3$ point of view, 


$$
\begin{aligned}
W_{T-2}^{0}\left(h_{T-2}^{c}, h_{p}\right)= & u\left[w_{p} h_{p}+w_{T-2}^{c}-e_{T-2}^{c}\left(w_{T-2}^{c}+p_{T-2}\right)\right] \\
& +\beta W_{T-1}^{0}\left(h_{T-1}^{c}, h_{p}\right)
\end{aligned}
$$

the policy $e_{T-3}^{c}=g\left(\delta, h_{T-2}^{c} ; h_{p}\right)$, the continuation value from the period $T-2$ point of view,

$W_{T-1}^{0}\left(h_{T-1}^{c}, h_{p}\right)=u\left[w_{p} h_{p}+w_{T-1}^{c}-\left(w_{T-1}^{c}+p_{T-1}\right) g\left(\delta, h_{T-1}^{c} ; h_{p}\right)\right]+\beta \nu\left(\phi\left[h_{T-1}^{c}, g\left(\delta, h_{T-1}^{c} ; h_{p}\right)\right]\right)$

and $h_{T-1}^{c}=\phi\left[h_{T-2}, g\left(\delta, h_{T-2}^{c} ; h_{p}\right)\right]$.

Consider $\partial W_{T-2}^{0}\left(h_{T-2}^{c}, h_{p}\right) / \partial h_{T-2}^{c}$. It can easily be established that

$$
\begin{aligned}
\frac{\partial W_{T-2}^{0}\left(h_{T-2}^{c}, h_{p}\right)}{\partial h_{T-2}^{c}}= & \frac{\partial g_{T-2}}{\partial h_{T-2}^{c}} \cdot\left[-\left[w_{T-2}^{c}+p_{T-2}\right] u^{\prime}\left(c_{T-2}\right)+\beta \frac{\partial W_{T-2}^{0}\left(h_{T-2}^{c}, h_{p}\right)}{\partial h_{T-2}^{c}} \phi_{e}\left(h_{T-2}^{c}, g_{T-2}\right)\right] \\
& +\beta \frac{\partial g_{T-1}}{\partial h_{T-1}^{c}} \cdot\left[-\left[w_{T-1}^{c}+p_{T-1}\right] u^{\prime}\left(c_{T-1}\right)+\beta \nu^{\prime}\left(h_{T}^{1}\right) \phi_{e}\left(h_{T-1}^{c}, g_{T-1}\right)\right] \phi_{h}\left(h_{T-2}^{c}, g_{T-2}\right) \\
& +\beta^{2} \phi_{h}\left(h_{T-2}^{c}, g_{T-2}\right) \nu^{\prime}\left(h_{T}^{1}\right) \phi_{h}\left(h_{T-1}^{c}, g_{T-1}\right)
\end{aligned}
$$

Note that the first two terms are negative due to strategic interaction. Therefore adding more periods worsen the effect of time -inconsistency in the sense that the future benefits of educating the child today becomes even smaller.

To solve for the complete sequence of education investments is simply a matter of continuing the procedure of backwards induction described here all the way back to the first period of the child's life. If the conditions of proposition 2 are satisfied, this means that adding more periods to the analysis will further aggravate the time-inconsistency problem but not qualitatively change our results, so from now on we restrict attention to the simple case $T=3$.

\subsection{A Reduction in Children's Wages}

An important policy issue in many prosperous countries today is whether to restrict imports of goods made using child labor. The professed objective of such policies would be to make 
children in poor countries better off by preventing their exploitation as workers. From the point of view of a poor household considering how to allocate children's time, the effect of such a policy would be perceived as a reduction in the wage for child labor. In this section we show that some families may indeed be better off, in an ex ante sense, as a result of such a policy. However these families are not necessarily the poorest ones; to benefit from a wage reduction, a family must have an income high enough that the child would attend school under the reduced wage.

Under standard preferences, an exogenous change in the children's wage reduces the welfare of those parents whose children were working before the change. In our model, it is possible that some parents are made better off by such a change. In this section we explore conditions required for this to happen.

For parents to gain from a reduction in the child's wage, there must be in increase in their indirect utility from the view point of period $T-2$. Their indirect utility is given by

$$
\begin{aligned}
W_{T-2}^{0}\left(h_{T-2}^{c}, h_{p}, w_{1}^{c}, p_{1}, p_{2}\right)= & u\left[w_{p} h_{p}+w_{1}^{c}-g_{1}\left(h_{T-2}^{c}, h_{p}, w_{1}^{c}, p_{1}, p_{2}\right)\left(w_{1}^{c}+p_{1}\right)\right] \\
& +\beta W_{T-1}^{0}\left(h_{T-1}^{c}, h_{p}, w_{p}, w_{1}^{c}, p_{2}\right)
\end{aligned}
$$

which includes their anticipated indirect utility from T-1:

$$
\begin{aligned}
W_{T-1}^{0}\left(h_{T-1}^{c}, h_{p}, w_{p}, w_{1}^{c}, p_{2}\right)= & u\left[w_{p} h_{p}+(1+\gamma) w_{1}^{c}-g_{2}\left(h_{T-1}^{c}, h_{p}, w_{1}^{c}, p_{2}\right)\left[(1+\gamma) w_{1}^{c}+p_{2}\right]\right] \\
& +\beta \nu\left(\phi\left[h_{T-1}^{c}, g_{2}\left(h_{T-1}^{c}, h_{p}, w_{1}^{c}, p_{2}\right)\right]\right)
\end{aligned}
$$

Now consider the effect, on parents' welfare, of an exogenous change in the basic child labor change, $w^{c}$. Denote this effect as $\partial W_{T-2}^{0}\left(h_{T-2}^{c}, h_{p}, w_{1}^{c}, p_{1}, p_{2}\right) / \partial w_{1}^{c}$. In appendix $A .2$ we prove the following result.

Proposition 3. Suppose that utility satisfies constant elasticity of substitution and parental education policies are in the interior of the choice set. Then there exists a threshold $\widetilde{h}(\delta)$ such that all parents with human capital levels $h_{p}>\widetilde{h}(\delta)$ are made better off by an exogenous reduction in child labor wages. Furthermore, the more severe the time-inconsistency problem, the larger the number of parents who can be made better off by an exogenous reduction in the child labor wage. 
It is obvious that the wage-reduction policy, by lowering the revenue of those families whose children acquire only a partial education, will reduce the education of these children even further. Even though very poor families are unambiguously worse off as the result of such policies, and their children less educated, there exists a potential justification for a policy banning imports of industries that employ children, in that it can indeed raise the education levels of children from families whose poverty is not as dire.

\section{Parametric Example}

In this section we consider a simple 2-period version of the model with logarithmic preferences and Cobb-Douglas technology. This specification implies that the strategic effect discussed earlier is absent. Some analytical results are possible for a sufficiently simple choice of time structure and functional forms. We restrict the analysis to education decisions over two periods of childhood corresponding to primary education (the first period) and secondary education (the second period). What do we lose by restricting the model in this way? Under the conditions of Proposition 2 above, the strategic interaction effect and the addition of more periods of education both intensify the time-inconsistency problem, so in a world characterized by these conditions, the simple version below could be considered a reducedform version of the full model, in which the time-inconsistency parameter $\delta$ is made smaller to reflect the two omitted effects.

Suppose that $T=3$, so that parents choose their children's activities for two periods. Let $u(c)=\ln c$ and $\nu\left(h_{T}^{1}\right)=A \ln h_{T}^{1}$, where $A>0$. Human capital in every state is now given by:

$$
h_{t}^{c}=\phi\left(h_{t-1}^{c}, e_{t-1}^{c}\right)=\left\{\begin{array}{cl}
h_{1}^{c} & t=1 \\
\left(h_{t-1}^{c}\right)^{\eta}\left(\underline{e}+e_{t-1}^{c}\right)^{1-\eta} & t>1
\end{array}\right.
$$

where $\eta>0$.

Notice that as long as $\underline{e}>0$, the functional form for the human capital accumulation technology allows for children to have positive human capital even in the absence of parental investment in schooling. Parents' problem in this context amounts to optimally choosing 
the education policy pairs, $\left(e_{1}^{*}, e_{2}^{*}\right)$. To characterize this optimal education policy pair, the following assumption will prove useful:

U.4 The exogenous variables $w_{1}^{c}, w_{2}^{c}, p_{1}$, and $p_{2}$ together satisfy the following condition

$$
\beta \eta=\frac{\left(w_{1}^{c}+p_{1}\right)(1+\underline{e})+\beta^{2} \eta A(1-\eta) p_{1}}{\left(w_{2}^{c}+p_{2}\right) \underline{e}-\beta A(1-\eta) p_{2}} .
$$

Furthermore,

$$
\underline{e}>\beta A(1-\eta)
$$

This assumption is made for purely technical reasons and its usefulness will be made precise below. The characterization of this optimal policy pair is a straightforward application of the problem-solving technique outlined in the previous subsection:

Lemma 2. Under U.4, the optimal education policy pair is given as follows:

$$
\left(e_{1}^{*}, e_{2}^{*}\right)=\left\{\begin{array}{cc}
(0,0), & \text { if } h_{p} \in\left[\underline{h}, \underline{H}_{1}(\delta)\right] \\
\left(g_{1}\left(\delta, h_{p}, p_{1}, w_{1}^{c}\right), 0\right) & \text { if } h_{p} \in\left(\underline{H}_{1}(\delta), \bar{H}_{1}(\delta)\right] \\
\left(1, g_{2}\left(\delta, h_{p}, p_{2}, w_{2}^{c}\right)\right) & \text { if } h_{p} \in\left(\bar{H}_{1}(\delta), \bar{H}_{2}(\delta)\right) \\
(1,1) & \text { if } h_{p} \in\left[\bar{H}_{2}(\delta), \bar{h}\right]
\end{array}\right.
$$

where

$$
\begin{aligned}
g_{1}\left(\delta, h_{p}, p_{1}, w_{1}^{c}\right) & =\frac{\beta \eta \bar{A}(\delta)}{1+\beta \eta \bar{A}(\delta)}\left[w\left(h_{p}, p_{1}, w_{1}^{c}\right)-\frac{\underline{e}}{\beta \eta \bar{A}(\delta)}\right] \\
g_{2}\left(\delta, h_{p}, p_{2}, w_{2}^{c}\right) & =\frac{\bar{A}(\delta)}{1+\bar{A}(\delta)}\left[w\left(h_{p}, p_{2}, w_{2}^{c}\right)-\frac{\underline{e}}{\bar{A}(\delta)}\right]
\end{aligned}
$$

and

$$
\begin{aligned}
& \underline{H}_{1}(\delta)=\left[\frac{\underline{e}}{\beta \eta \bar{A}(\delta)}\left(1+\frac{p_{1}}{w_{1}^{c}}\right)-1\right] \frac{w_{1}^{c}}{w_{p}} ; \\
& \bar{H}_{1}(\delta)=\left[\frac{(1+\underline{e})}{\beta \eta \bar{A}(\delta)}\left(1+\frac{p_{1}}{w_{1}^{c}}\right)+\frac{p_{1}}{w_{1}^{c}}\right] \frac{w_{1}^{c}}{w_{p}} ; \\
& \bar{H}_{2}(\delta)=\left[\frac{(1+\underline{e})}{\bar{A}(\delta)}\left(1+\frac{p_{2}}{w_{2}^{c}}\right)+\frac{p_{2}}{w_{2}^{c}}\right] \frac{w_{2}^{c}}{w_{p}} \\
& w\left(h_{p}, p_{1}, w_{1}^{c}\right)=\frac{w_{p} h_{p}+w_{1}^{c}}{p_{1}+w_{1}^{c}} ; \quad w\left(h_{p}, p_{2}, w_{2}^{c}\right)=\frac{w_{p} h_{p}+w_{2}^{c}}{p_{2}+w_{2}^{c}} ; \\
& \bar{A}(\delta)=\delta \beta A(1-\eta), \text { with } \underline{h} \leq \underline{H}_{1}(\delta)<\bar{H}_{1}(\delta)<\bar{H}_{2}(\delta) \leq \bar{h} .
\end{aligned}
$$


Condition (3.2) of Assumption U.4 simply guarantees that the end-values $\underline{H}_{1}(\delta), \bar{H}_{1}(\delta)$, and $\bar{H}_{2}(\delta)$ are all positive. Condition (3.1) on the other hand ensures that $\underline{h} \leq \underline{H}_{1}(\delta)<$ $\bar{H}_{1}(\delta)<\bar{H}_{2}(\delta) \leq \bar{h}$, so that the union of the intervals $\left[\underline{h}, \underline{H}_{1}(\delta)\right],\left(\underline{H}_{1}(\delta), \bar{H}_{1}(\delta)\right],\left(\bar{H}_{1}(\delta), \bar{H}_{2}(\delta)\right)$, $\left[\bar{H}_{2}(\delta), \bar{h}\right]$ is indeed the set of all parents (i.e., the interval $[\underline{h}, \bar{h}]$ ). Note the dependence of the size of the respective ranges on the time-inconsistency parameter, $\delta$. This implies that the distribution of the population of parents across these ranges is affected by the degree of severity of the time-inconsistency problem.

How does the optimal level of compulsory education depend on the parental state? The following Proposition summarizes the answer to that question:

Proposition 4. The more severe the time-inconsistency problem, (i) the larger the number of parents who choose not to educate their children in all periods (i.e., parents who choose $\left.\left(e_{1}^{*}, e_{2}^{*}\right)=(0,0)\right)$; and (ii) the smaller the number of parents who choose to educate their children full-time in all periods (i.e., those who choose $\left(e_{1}^{*}, e_{2}^{*}\right)=(1,1)$ ).

$\mathbf{P}$ roof. It suffices to note that $\underline{H}_{1}(\delta)$ (respectively $\bar{H}_{2}(\delta)$ ) is higher the smaller $\delta$ (i.e., the more severe the time-inconsistency problem).

Proposition 4 is the parametric analog of proposition 2; it establishes the inefficiency of parental education policies due to the time-inconsistency problem. Since both $\underline{H}_{1}(\delta)$ and $\left.\bar{H}_{2}(\delta)\right)$ decreasing in $\delta$, and $\delta \in[0,1]$, for parents whose human capital levels fall within the range $\left[\underline{h}, \underline{H}_{1}(1)\right]$ or $\left[\bar{H}_{2}(1), \bar{h}\right]$, time-inconsistency is not a problem. Parents with human capital in the interval $\left[\underline{h}, \underline{H}_{1}(1)\right]$ are just too poor to afford to give up on income from child labor sources, hence $\left(e_{1}^{*}, e_{2}^{*}\right)=(0,0)$. In contrast, parents with human capital in the interval $\left[\bar{H}_{2}(1), \bar{h}\right]$ are rich enough to pass on the opportunity to supplement household income with income from child labor sources, hence $\left(e_{1}^{*}, e_{2}^{*}\right)=(1,1)$.

\subsection{Who Gains from Compulsory Education Laws?}

To address this question, it is important to first ask if they are parents who can be made worse off by the imposition of compulsory education laws. According to Proposition 4 above, the only parents who stand to lose from the imposition of compulsory education laws are 
those with human capital levels in the open range, $\left[\underline{h}, \underline{H}_{1}(1)\right]$, because they are too poor to send their children to school even without time-inconsistency. Therefore, we know that parents with human capital levels in the open range $T(\delta)=\left(\underline{H}_{1}(1), \bar{H}_{2}(\delta)\right)$ are those whose child's education decisions suffer from the time-inconsistency problem, and thus stand to gain from the imposition of such laws. It is clear that the size of this critical range is decreasing in $\delta$, as

$$
\frac{d}{d \delta} \bar{H}_{2}(\delta)<0
$$

implying that the number of parents who gain from the imposition of compulsory education laws is larger the more severe the time-inconsistency problem.

Now if the critical range, $T(\delta)$, can be shown to be always non-degenerate for all $\delta \in$ $[0,1]$, then, under the assumption that the distribution of parents' human capital levels is continuous with strictly positive density over its entire support, there always would exist parents who gain from the imposition of compulsory education laws. Indeed, the following result can be easily established:

Proposition 5. Suppose the distribution of parents' human capital levels is continuous with strictly positive density over its entire support. Under $U_{4}, T(\delta)$ is always non-degenerate for all $\delta \in[0,1]$.

$\mathbf{P}$ roof. Since the cardinality of $T(\delta)$ is decreasing in $\delta$, it suffices to show that the smallest possible problematic region is non-degenerate under U4. This smallest possible region therefore is $T(1)=\left(\underline{H}_{1}(1), \bar{H}_{2}(1)\right)$. Observe therefore that under U4,

$$
\underline{H}_{1}(1)<\bar{H}_{1}(1)=\underline{H}_{2}(1)<\bar{H}_{2}(1)<\bar{h},
$$

which implies that there always exists $h_{p}$ such that $\underline{H}_{1}(1)<h_{p}<\bar{H}_{2}(1)$. Hence the result.

Proposition 5 formalizes the emergence of compulsory education laws as the outcome of a conflict between poor parents - i.e., those with human capital in the range $\left[\underline{h}, \underline{H}_{1}(1)\right]-$, and not-so-poor parents - i.e., those with human capital levels in the critical range, $T(\delta)$. We interpret the latter as the middle class. Parents with human capital levels in the range 
$\left[\bar{H}_{2}(\delta), \bar{h}\right]$ are indifferent, as they neither gain nor lose from the imposition of compulsory education laws. This is because they are rich enough so that they always choose to enroll their children in school full time, despite facing time-inconsistent preferences. Countries therefore will adopt compulsory education laws when a critical mass of parents enter the range delimited by $T(\delta)$, otherwise they will be permissive towards child labor. ${ }^{5}$

\section{Child Labor in Latin America}

In this section, we analyze a cross-country dataset, comprised of the results of representative household surveys of 12 countries in Latin America, to compile an index of the permissiveness of each country towards child labor. These indices reflect the extent to which the country of residence helps to predict whether children are in the labor force, controlling for family characteristics, such as income and education, and are measured as the country fixed effects in OLS regressions with child employment measures as the dependent variables. We find that there are indeed significant country effects, after controlling for parental income. ${ }^{6}$ At the end of this section, we show how these indices relate to per capita GDP and whether the country is a signatory to convention C-138. In addition, we show that whether a child is in the labor force is strongly correlated with measures of education, such as whether the child is attending school, and how many years of schooling the child is lagging behind the

\footnotetext{
${ }^{5} \mathrm{~A}$ caveat of our theoretical analysis is the deliberate exclusion of the preferences of non-parents (e.g., grand-parents or childless individuals) in the characterization of the size and composition of the coalition supporting compulsory education laws. It is possible that the inclusion of this class of individuals may provide another channel through which political support for compulsory education can emerge, as in Doepke and Zilibotti (2005).

${ }^{6}$ Earlier versions of these surveys have been used previously to analyze similar issues, as in Psacharopoulos (1997), who examined the relationship between child labor and educational attainment in Bolivia and Venezuela, and by Moe (1998), who analyzes fertility and human-capital investment in Peru. Szekely and Hilgert (1999) use these surveys to analyse the sources of income inequality across the different countries, while Dahan and Gaviria (1999) analyze the relationships between social mobility and marital sorting on the one hand, and income inequality on the other.
} 
maximum potential years for her age.

Child labor is inherently difficult to measure; much of it is unpaid work, often for family members around the house or the farm. It is also possible that parents suppress information on their children's work, and for some countries, children's labor variables are automatically set to zero for children younger than 12. Even though the dataset in question includes direct measures of child labor, such as hours worked, labor income, and an indicator of the child's employment, it is likely that these variables understate significantly the prevalence of child labor. Therefore we also use indirect measures, such as whether children are attending school, and the gap between potential and reported years of education.

For each measure $L_{i, j}$ of the labor of child $i$ in country $j$, we estimate the following equation on the characteristics $x_{i}$ of the child's family:

$$
L_{i, j}=\alpha_{j}+\beta x_{i}+\varepsilon_{i, j}
$$

One of the most important specification decisions is whether fertility or family size should be included in the family characteristics. The argument for including some measure of the number of children is that children add to the household's desired consumption, while older children potentially increase the family's income, with their own labor capacity. Hence families with more children may either be more inclined to send a working age child to work, if the other children are younger, or less inclined, if the other children are older. However we believe that such measures should be excluded, because fertility decisions are themselves responses to child-labor conditions. Under standard, Beckerian fertility models, such as Becker, Murphy, and Tamura (1990), child labor reduces the cost of having children, and hence increases fertility ${ }^{7}$. Therefore controlling for fertility would bias the estimate of the country's effect on fertility, by falsely attributing to fertility part of the effect that is due to the status of child labor in the household's country. ${ }^{8}$ The variables that we would like to include are those indicators that standard theory suggests are relevant for the child-labor decision, but not strongly dependent on that decision, such as parental education and family

\footnotetext{
${ }^{7}$ See Doepke (1999) for a model in which this interaction plays a key role in economic development.

${ }^{8}$ For a recent theoretical analysis of fertility and child labor, see Doepke (1999).
} 
income net of child labor.

\subsection{The Data}

The data set in question is a compendium of representative household surveys of 12 countries in Latin America; we study the 112,227 children aged 10-17 in these surveys. Despite the large number of households, this is a small sample in terms of number of countries, but it proved impossible to extend the analysis to other countries because most surveys ignore labor force participation of children. ${ }^{9}$ The advantage of focusing on Latin America is that these countries are quite similar in many ways; polygamy is not an accepted practice, nomadic peoples are the exception, and European education traditions are well established.

Earlier versions of these surveys have been used individually to analyze similar issues, as in Psacharopoulos (1997), who examined the relationship between child labor and educational attainment in Bolivia and Venezuela, and by Moe (1998), who analyzes fertility and humancapital investment in Peru. These surveys have also been used previously in the literature on income inequality. Szekely and Hilgert (1999) show that these surveys indicate a wide variation in the degree of income inequality across the different countries, while Dahan and Gaviria (1999) use this data to analyze social mobility and income inequality. The data include education and labor earnings variables for all members of sample families.

The sample is restricted to single-family households with children in the age range 1017 that reported positive family income. The lower bound of the age range represents the earliest age at which most countries collect child labor information, and the upper bound the oldest age at which children are generally in secondary education. The key assumption behind this age range is that children have significant labor capacity, and that it is the parents who are deciding the children's time allocation across work and education. To the extent that household patterns vary systematically across countries, it may be necessary to

\footnotetext{
${ }^{9}$ Uruguay reports labor force behavior for children over the age of 14, but was excluded because it does not cover children under that age. Another limitation of our data set is that Argentina and Ecuador cover only urban households.
} 
relax the criterion of single-family households.

Child labor is inherently difficult to measure; much of it is unpaid work, often for family members around the house or the farm. It is also possible that parents suppress information on their children's work, and for some countries, children's labor variables are automatically set to zero for children younger than 12. Even though the dataset in question includes direct measures of child labor, such as hours worked, labor income, and an indicator of the child's employment, it is likely that these variables understate significantly the prevalence of child labor. Therefore we also use indirect measures, such as whether children are attending school, and the gap between potential and reported years of education.

Income and wages have been converted to U.S. currency, by equating purchasing power parity across countries to the U.S. level, using measures published by the OECD. The table shows the averages for several key variables: number of children per family, hours that employed children spend in paid employment, the income of employed children, the age of the child, and the total income of the family, excluding children's earnings. These are reported by the age-group of children, ages 10-14 and 15-17.

Table 1 shows some basic descriptive statistics for the data. First it is clear that the rate of child labor is much higher for the older group of children. In Venezuela for instance only $4 \%$ of children aged 10-14 work but among the $15-17$ year-olds, the rate is $17.7 \%$. Second there is significant variation in the employment rate of both groups. For the younger group, employment rates range from 1 per cent in Argentina and Chile to over 14\% in Bolivia, $13 \%$ in Brazil and $11 \%$ in Mexico. Third the employment rates of both groups appear highly correlated across countries: the Pearson correlation coefficient is 0.94. Similarly, school attendance rates are also highly correlated: the Pearson coefficient is 0.82 . Fourth, there is a significant negative correlation ( -0.39 for the older group) between employment and school attendance. Similar results hold for the other measures of education reported in the table, such as years of education and the education gap, which equals the potential education of the child as a function of age, less the attained education, measured in years.

The basic premises of the analysis appear to be present in the data: higher rates of 
schooling among younger children, and a tradeoff between child labor and education. The correlation between the younger and older children's employment and schooling rates suggests that the same forces are at work for both groups. Moreover, these properties seem to be robust to the exact measure used of labor or education. Finally, the presence of wide variation in employment rates across countries makes accounting for this variation an economically interesting exercise.

\subsection{Child Labor and Education}

A key assumption in the paper is that child labor reduces education. Some empirical evidence for this assumption is presented in Table 2. The table shows results for a probit regression in which the dependent variable is an indicator equal to one for children in school, and zero otherwise. The explanatory variables include, in addition to a dummy variable for each country, an employment variable, the age of the child and family characteristics, such as household income, father's education and number of children aged less than 6 years old. The country fixed effects (ie the coefficient estimates on the dummy variables) are shown in Table A6. The employment variable is set to 1 if children worked 10 hours per week or more, zero otherwise. Age variables are based on deviations from the mean, while income variables appear as deviations from the median; both appear in the regression equation as the logs and the squares of the logs.

How strong is the estimated effect of employment on education? Consider a family in which the parents have 6 years of education each, and earn the median income. Suppose they live in Chile, where the fixed effect (coefficient estimate on the dummy variable) is 1.43. The results suggest that employment reduces the probability that a child aged 10-13 attends school from $97 \%$ to $82 \%$ for boys and from $95 \%$ to $86 \%$ for girls. For a country like Bolivia, where the fixed effect is smaller, the estimated effect of employment is much larger: the school attendance probability falls from $80 \%$ to $47 \%$ for boys aged $10-13$.

An alternative measure of the impact of child labor on education is the education gap.

Table 3 shows OLS estimation results for a regression of the education gap on the same 
explanatory variables described above. The country fixed effects are shown in Table A7. The estimates suggest that employment increases the gap by 0.32 years for boys in the younger group, and by 0.2 years for girls. For the older group, the estimates are 0.85 and 0.27 , respectively. These numbers are associated with high t-values, and reinforce the impression from the previous table, that child labor competes with education in the allocation of children's time. While these numbers do not seem large as a percent of average educational attainment, it is likely that children with interrupted schooling will not return; hence a positive gap indicates that attainment will not increase with age. This argument is explored explicitly in Psacharapoulos (1981), who analyzes the education gaps associated with child employment in Peru.

Obviously there is no attempt here to deal with unobserved heterogeneity or with colinearity among the explanatory variables. If less able students were more likely to leave school, then these estimates would represent upper limits on the effect of child labor. On the other hand, assuming that parental income does not directly affect education, the bias resulting from co-linearity between employment and family income is clearly towards understating our result: children with low income do worse in school, holding ability constant, because they are more likely to be employed. In the absence of further evidence, it is reasonable to assume that the results are not driven by bias from omitted variables, and hence we conclude that child labor does indeed have a large and significant effect on educational attainment.

\subsection{Country Effects on Child Employment}

To see how child-labor patterns vary across countries, we report in Tables 4 a) and b) results for a regression of child labor-hours on parental income, parental education and the age of the child, as well as a set of dummy variables representing country effects for each country (the country effects are reported in Table 4b). The table shows that children's hours are higher among the older age group of children, and that the cross-country patterns are otherwise similar across age groups. Parental income reduces the probability of child employment, as 
does education of the parents, with mother's education having a slightly larger effect than father's education. Hence the impression that emerges is that child labor is a response to poverty, and parents use higher income to purchase more time in education for their child.

The main message of the country fixed-effects in the table is that child labor participation depends on the country of origin, even after controlling for parental income. The unexplained component of children's hours is significantly higher in Bolivia, Brazil, Paraguay and Peru than in the other countries. The economic significance of the fixed effect is that the childlabor probability is a function of cross-country differences; in the next section we show the extent to which these differences are associated with aggregate observables such as GDP per capita. First however it is important to ask whether the effects are economically significant. In Table A5 we use the estimates to predict child labor rates under the counter-factual assumption that all countries have the same effect as Chile. We find that the average rate of child labor drops from $11 \%$ to $4 \%$ for boys aged 10-14, and from $29 \%$ to $15 \%$ for boys aged $15-17$. For girls aged $10-14$, the drop is from $5 \%$ to $2 \%$ and for the older girls from $13 \%$ to under $6 \%$. Therefore child labor is not merely a matter of parental poverty: there is a significant social effect as well.

It turns out that Bolivia, Peru and Paraguay are the poorest countries in the sample, on a per-capita basis, while Brazil has the most unequal distribution of income ${ }^{10}$. Hence it is likely that the common denominator across countries with high child labor is indeed a low median income, as suggested by the model. Countries where child labor is least likely, controlling for parental income are Argentina, Panama and Chile; hence the fact that two of these are the most prosperous countries in the sample supports the idea that there is an income-based explanation of the country-effects on child labor.

\footnotetext{
${ }^{10}$ See Facing up to Inequality in Latin America, 1998, Inter-American Development Bank, Washington, D.C.
} 


\subsection{Explaining the Country Effects}

We interpret the fixed effects estimated in Table 4 as indicators of the permissiveness of the countries in question towards child labor. In this section we examine how these effects are correlated with per capita income and with whether a country has ratified the ILO's C-130 convention against child labor.

Table 5 shows how these estimated fixed effects relate to per capita GDP. The relation between GDP and the child labor fixed effect is negative, and often quite strongly so; the estimated coefficient is shown in the row labeled " $\log (\mathrm{GDP})$ ", and below it the standard error, the t-statistic, the probability of the t-statistic under the null hypothesis, and the R-squared coefficient. ${ }^{11}$ The country-GDP relation is much stronger for girls in both age groups than for boys; labor supply of girls declines more quickly with per capita GDP. It is significant that in all cases, the relationship is stronger for the younger age group than for the older, which is consistent with our interpretation, as we would expect more restrictions on child labor for the younger age group. This strong relation between GDP and the country effects suggests that an increase in GDP reduces child labor not only via higher family income of high-risk families, but also via some aggregate effect.

It is encouraging therefore to note the consistently negative correlation between these effects on the one hand, and a country's support of convention C-138 on the other. While these correlations, reported in the final two rows of Table 5, is not statistically significant on an individual basis, the negative sign suggests that countries which we find more open to child labor are less likely to have officially endorsed the convention against child labor, which is what one would expect if our indices are in fact reflecting the hostility of the general legal and political climate of a country towards child labor.

Robustness is of course a major issue in this type of regression analysis, particularly with so few data points. An important possibility is that the explanatory variable is actually reflecting the effect of some other variables with which it is correlated. These indicators of child labor are essentially residuals, and hence do not distinguish between the effects of child

\footnotetext{
${ }^{11}$ Quadratic terms had very little effect on R-squared, so these higher-order regressions are not reported.
} 
labor laws and other factors omitted from the regression that may also influence child labor. This issue is addressed in Table A4, which shows the effect of including a second aggregate variable in the regression of the country effects on GDP per capita. The variabes are chosen because they appear frequently in the literature on poverty and development, and are not motivated by implications of the model. For instance a more general model that allows for fertility choice would imply that children are cheaper when child labor is more likely, so that fertility should be correlated with mandatory education, and hence income. This of course would violate the orthogonality assumption of the OLS model.

The variables, whose values are given in Table A3, are the Gini coefficient for income, the total fertility rate, the percent of the country's GDP accounted for by agriculture, and the rate of return to education. This last variable, the Mincer coefficient, is taken from Bils and Klenow (2000). The result is that the sign of the GDP effect remains negative in all cases. The estimates are statistically significant for girls, while for boys the GDP effect is no longer statistically significant when other variables are added to the regression. This is to be expected due to the small size of the sample. Furthermore, in the most successful models, such as the girls 10-13, particularly the specification with agriculture, the GDP coefficient is more significant than in the single-variable regression, and R-squared much higher.

In conclusion, it appears that GDP per capita does inhibit child labor, even after taking into account household income. The sample is too small to allow multi-variate analysis, but the finding appears robust to inclusion of other variables. The estimated country effects behave as one might expect for an indicator of child labor permissiveness: they are negatively correlated with ratification of the ILO's anti-child labor convention, and they are stronger for young children than for older.

\section{Conclusion}

This paper asked how laws against child labor might emerge. Our motivation for asking this question is that while standard theory does not seem to explain households voting for such laws, these laws are often credited with a significant role in reducing child labor. 
We presented a theory of child labor based on the assumption that parents have timeinconsistent preferences and showed how, in the absence of other institutions allowing parents to commit, child labor laws may increase the welfare of poor households in an ex ante sense by allowing parents to achieve a higher level of education for their children than they would be able to achieve with an unconstrained choice set. Our model does not require parents somehow to be able to commit to laws. We showed that compulsory education laws emerge when a critical mass of parents has income in an intermediate interval that depends on the returns to the parent of the child's education. We interpreted this group as the middle class, and provided supporting evidence that this class was indeed part of the social movement that led to adoption of compulsory education laws in several countries including the US.

We then presented an empirical analysis of child labor in Latin America that supports the hypothesis that the country of residence has an effect on the propensity of children to work. We showed that child labor is indeed strongly affected by country of residence, as in our model. Were all countries in our sample to be similar in this respect to Chile, our computations implied the average rate of child labor would fall from 11\% for boys aged 10-14 to a little over $3 \%$. We also showed that this effect is more strongly negative in countries with higher levels of per capita income. Robustness checks reported in the Appendix suggest that this correlation is not explained by cross-country variations in the return to education, nor by other plausible candidates, such as the share of agriculture in GDP or the fraction of the population living in urban areas. We interpreted this country effect on child labor as consistent with the effects of variations in child labor laws, noting the consistently negative correlation with whether the country had officially endorsed the ILO's conventions C-138 against child labor.

From the point of view of assessing the long-run benefits of policies restricting child labor, however, an obvious short-coming of this model is that it takes as given the distribution of human capital in the economy. However the static model is sufficiently simple that nesting it into a dynamic model of the income distribution, as in Galor and Zeira (1993), is relatively straight-forward. Thus we can see the current paper as a building block towards assessing 
the effects of efforts to lower the demand for child labor. In future research, such dimensions as endogenous fertility and political choice of education quality can be integrated into the model; the structure presented here is a minimal framework that may yield its own family of models in the future. 


\section{References}

Baland, J.-M., and J. A. Robinson (2000): "Is Child Labor Inefficient?," Journal of Political Economy, 108(4), 663-679.

Basu, K. (1999): "Child Labor: Cause, Consequence, and Cure, with Remarks on International Labor Standards," Journal of Economic Literature, XXXVII (3), 1083-1119.

Becker, G. S. (1976): The Economic Approach to Human Behavior. University of Chicago Press, Chicago, IL and London,UK.

Becker, G. S., K. M. Murphy, and R. Tamura (1990): "Human Capital, Fertility and Economic Growth," Journal of Political Economy, 98(5, pt. 2).

Behrman, J., P. E. Todd, and P. Sengupta (2005): "Progressing through PROGRESA: An Impact Assessment of a School Subsidy Experiment in Rural Mexico," Journal of Economic Development and Cultural Change, 54(1).

Bils, M., and P. J. Klenow (2000): "Does Schooling Cause Growth?" American Economic Review, 90 (5), 1160-83.

Cain, M. T. (1977): "The Economic Activities of Children in a Village in Bangladesh," Population and Development Review, 3(3), 201-27.

Dahan, M., and A. Gaviria (1999): "Sibling Correlations and Intergenerational Mobility in Latin America," Mimeo,IDB.

Dessy, S. (2000): "A Defense of Compulsory Measures against Child Labor," Journal of Development Economics, 62(1), 261-275.

Doepke, M. (1999): "Growth and Fertility in the Long Run," Mimeo,University of Chicago.

Doepke, M., and D. Krueger (2006): "Origins and Consequences of Child Labor Restrictions: A Macroeconomic Perspective," NBER Working Papers: 12665. 
Doepke, M., and F. Zilibotti (2005): "The Macroeconomics of Child Labor Regulation," American Economic Review, 95(5), 1492-1524.

Eckstein, Z., and I. Zilcha (1994): "The Effects of Compulsory Schooling on Growth, Income Distribution and Welfare," Journal of Public Economics, 54(3), 339-59.

Fang, H., and D. Silverman (2000): "Dole Meets Laibson: On the Compassion of Timelimited Welfare," Mimeo,University of Pennsylvania.

Fyfe, A. (2005): "Compulsory Education and Child Labour: Historical Lessons, Contemporary Challenges and Future Directions," Working paper.

Galor, O., and J. Zeira (1993): "Income Distribution and Macroeconomics," Review of Economic Studies, 60(1), 35-52.

Glomm, G. (1997): "Parental Investment in Human Capital," Journal of Development Economics, 53 (3), 99-114.

Goldin, C. (1979): "Household and Market Production of Families in a Late-Nineteenth Century American Town," Explorations in Economic History, 16(2), 111-31.

Grootaert, C., and R. Kanbur (1995): "Child Labor: An Economic Perspective," International Labor Review, 134(2), 187-203.

KleinberG, S. J. (2005): "ChildrenŠs and MothersŠ Wage Labor in Three Eastern U.S. Cities, 1880-1920," Social Science History, 29(1), 45-76.

Krusell, P., and T. Smith (2003): "Consumption and Savings Decisions with QuasiGeometric Discounting," .

Laibson, D. (1997): "Golden Eggs and Hyperbolic Discounting," Quarterly Journal of Economics, 0, 443-477.

Laibson, D., A. Repetto, and J. Tobacman (1998): "Dynamic Choices of Hyperbolic Consumers," Mimeo, Harvard University. 
Loury, G. C. (1981): "Intergenerational Transfers and the Distribution of Earnings," Econometrica, 49(4), 843-867.

Moe, K. S. (1998): "Fertility, Time Use and Economic Development," Journal of Political Economy, 1, 699-718.

Mullainathan, S. (2006): "Development Economics through The Lens of Psychology," in Proceedings of the Annual Bank Conference on Development Economics, p. forthcoming.

Psacharapoulos, G. (1981): "Returns to Education; an Updated International Comparison," Comparative Education, 17, 321-341.

Psacharopoulos, G. (1997): "Child Labor Versus Educational Attainment: Some Evidence from Latin America," Journal of Population Economics, 10, 377-386.

Rosenzweig, M., and R. Evenson (1977): "Fertility, Schooling and the Economic Contribution of Children in Rural india," Econometrica, pp. 1065-1079.

Strotz, R. H. (1955): "Myopia and Inconsistency in Dynamic Utility Maximization," Review of Economic Studies, 23(3), 165-80.

Szekely, M., And M. Hilgert (1999): "What's Behind the Inequality We Measure: An Investigation Using Latin American Data for the 1990's," Mimeo, Inter-American Development Bank.

Todd, P. E., And K. I. Wolpin (2006): "Assessing the Impact of a School Subsidy Program in Mexico: Using a Social Experiment to Validate a Dynamic Behavioral Model of Child Schooling and Fertility," American Economic Review, 96(5), 1384-1417.

US Department of Labor (1998): By the Sweat and Toil of Children (Volume V) Efforts to Eliminate Child Labor. U.S. Department of Labor Bureau of International Labor Affairs, http://www.dol.gov/ilab/media/reports/iclp/sweat5/. 
WeIner, M. (1991): The child and the state in India: Child labour and educational policy in comparative perspective. Princeton University Press, Princeton.

\section{Appendix A.2}

To prove proposition 3, it suffices to prove the following two claims: (i) there exists a range of parental human capital such that all parents with human capital within this range can be made better off by an exogenous reduction in the child labor wage; (ii) this range is wider the more severe the time inconsistency problem. We begin with the first claim.

Claim 1. Assume u(.) has constant elasticity of substitution. Then, there exists a threshold $\widetilde{h}(\delta)$ such that

$$
\frac{\partial}{\partial w_{1}^{c}} W_{T-2}^{0}\left(\delta, h_{T-2}^{c}, h_{p}, w_{1}^{c}, p_{1}, p_{2}\right)<0
$$

if $h_{p}>\widetilde{h}(\delta)$, where $\widetilde{h}(\delta)$ is solution to $f\left(h_{p}\right)=1$.

$$
\frac{\beta(1+\gamma)^{2}\left(w_{p} h_{p}-p_{2}\right) u^{\prime}\left[w_{p} h_{p}+(1+\gamma) w_{1}^{c}\right]}{\left[(1+\gamma) w_{1}^{c}+p_{2}\right]\left[\bar{\delta} u^{\prime}\left(w_{p} h_{p}-p_{1}\right)+\beta \delta(1+\gamma) u^{\prime}\left(w_{p} h_{p}-p_{2}\right)\right] \bar{\epsilon}}=1 .
$$

Furthermore, $\widetilde{h}(\delta)$ is increasing in $\delta$.

$\mathbf{P}$ roof. From the expression $\frac{\partial}{\partial w_{1}^{c}} W_{T-2}^{0}\left(\delta, h_{T-2}^{c}, h_{p}, w_{1}^{c}, p_{1}, p_{2}\right)$, one can show that for any parent whose choice of education policies satisfies $e_{j}^{*} \in(0,1), j=1,2$, a necessary condition for him/her to experience a welfare gain from an exogenous reduction in the child labor wage is that his/her human capital, $h_{p}$, satisfies

$$
\frac{\partial g_{2}}{\partial w_{1}^{c}}<-\frac{\left[(1-\delta)\left(w_{1}^{c}+p_{1}\right)+\delta\left(1-e_{1}^{*}\right)\right] u^{\prime}\left(c_{1}^{*}\right)+\beta \delta(1+\gamma)\left(1-e_{2}^{*}\right) u^{\prime}\left(c_{2}^{*}\right)}{\beta(1+\gamma)\left[(1+\gamma) w_{1}^{c}+p_{2}\right] u^{\prime}\left(c_{2}^{*}\right)}
$$

Using the Implicit function theorem to characterize $\partial g_{2} / \partial w_{1}^{c}$, it can therefore be established that a sufficient condition for some parents to be made better off by a reduction child labor wages is that $f\left(h_{p}\right)>1$, where

$$
f\left(h_{p}\right)=\frac{\beta(1+\gamma)^{2}\left(w_{p} h_{p}-p_{2}\right) u^{\prime}\left[w_{p} h_{p}+(1+\gamma) w_{1}^{c}\right]}{\left[(1+\gamma) w_{1}^{c}+p_{2}\right]\left[\bar{\delta} u^{\prime}\left(w_{p} h_{p}-p_{1}\right)+\beta \delta(1+\gamma) u^{\prime}\left(w_{p} h_{p}-p_{2}\right)\right] \bar{\epsilon}} .
$$


The result of claim 1 thus simply follows from the fact that $f^{\prime}>0$, implying that $f\left(h_{p}\right)>$ $f[\widetilde{h}(\delta)]$.

Claim 2. Let

$$
\bar{\epsilon}<\frac{w_{p} \underline{h}+(1+\gamma) w_{1}^{c}}{w_{p} \bar{h}-p_{2}}
$$

and suppose

$$
\frac{u^{\prime}\left(w_{p} h_{p}-p_{2}\right)}{u^{\prime}\left(w_{p} h_{p}-p_{1}\right)}>\frac{w_{1}^{c}+p_{1}-1}{\beta(1+\gamma)} .
$$

Then, the more severe the time-inconsistency problem, the larger the interval for parental human capital within which a parent benefits from an exogenous reduction in the child labor.

$\mathbf{P}$ roof. I suffices to show that $\widetilde{h}^{\prime}>0$. First, rearrange equation (6.1) as follows

$$
G\left(h_{p} ; \delta\right)=0
$$

where

$$
\begin{aligned}
G\left(h_{p} ; \delta\right) \equiv & \beta(1+\gamma)^{2}\left(w_{p} h_{p}-p_{2}\right) u^{\prime}\left[w_{p} h_{p}+(1+\gamma) w_{1}^{c}\right] \\
& -\left[(1+\gamma) w_{1}^{c}+p_{2}\right]\left[\bar{\delta} u^{\prime}\left(w_{p} h_{p}-p_{1}\right)+\beta \delta(1+\gamma) u^{\prime}\left(w_{p} h_{p}-p_{2}\right)\right] \bar{\epsilon}
\end{aligned}
$$

Second, using the definition of $\bar{\epsilon}$, it can be shown that

$$
\begin{aligned}
G_{h}\left(h_{p} ; \delta, \bar{\epsilon}\right)= & (1+\gamma)^{2} w_{p} u^{\prime}\left[w_{p} h_{p}+(1+\gamma) w_{1}^{c}\right]\left[1-\frac{\left(w_{p} h_{p}-p_{2}\right) \bar{\epsilon}}{w_{p} h_{p}+(1+\gamma) w_{1}^{c}}\right] \\
& -\bar{\epsilon} w_{p}\left[(1+\gamma) w_{1}^{c}+p_{2}\right]\left[\bar{\delta} u^{\prime \prime}\left(w_{p} h_{p}-p_{1}\right)+\beta \delta(1+\gamma) u^{\prime \prime}\left(w_{p} h_{p}-p_{2}\right)\right]
\end{aligned}
$$

which is necessarily positive, due to condition (6.3). Furthermore,

$$
G_{\delta}\left(h_{p} ; \delta\right)=-\bar{\epsilon}\left[(1+\gamma) w_{1}^{c}+p_{2}\right]\left[\left(w_{1}^{c}+p_{1}-1\right) u^{\prime}\left(w_{p} h_{p}-p_{1}\right)-\beta(1+\gamma) u^{\prime}\left(w_{p} h_{p}-p_{2}\right)\right]
$$

which is negative by condition (6.4). The result then follows from the application of the Implicit function theorem. EndProof 
Figure 1: Child Labor: by Country, 1998

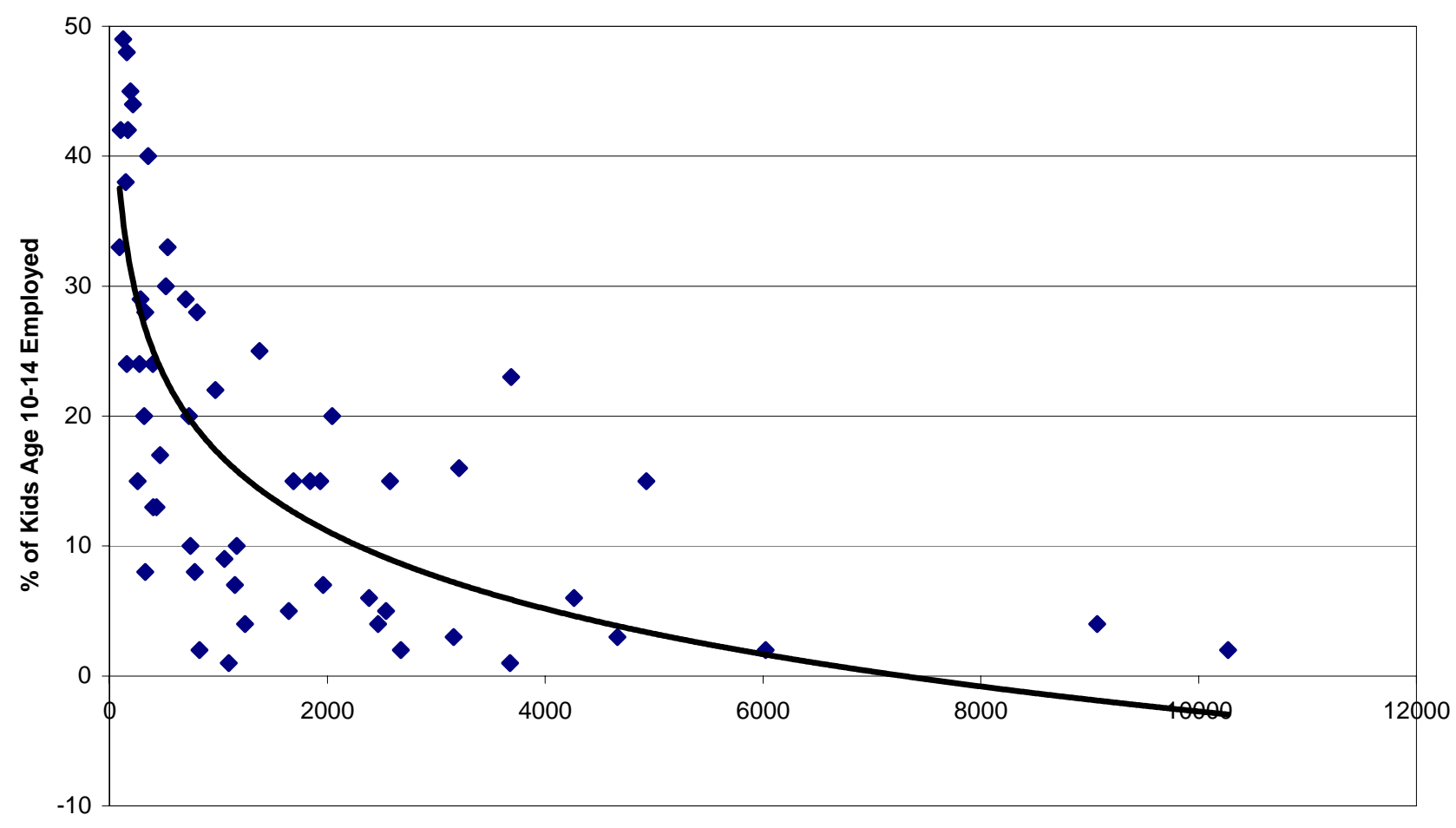

Per Capita Income (US \$97)

Source: UNDP Human Development Report 
Table 1: Children's Characteristics by Country

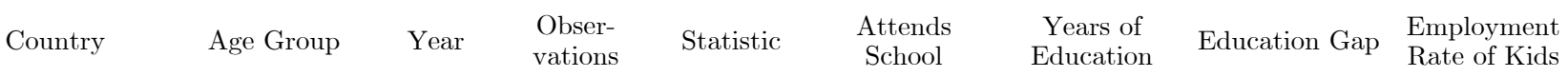

\begin{tabular}{|c|c|c|c|c|c|c|c|c|}
\hline \multirow{2}{*}{ Argentina } & 10 to 14 & 1996 & 689 & $\begin{array}{l}\text { mean } \\
\text { std. }\end{array}$ & $\begin{array}{c}0.95 \\
(4.5439)\end{array}$ & $\begin{array}{c}5.35 \\
(38.5467)\end{array}$ & $\begin{array}{c}0.67 \\
(32.2607)\end{array}$ & $\begin{array}{c}0.012 \\
(2.2804)\end{array}$ \\
\hline & 15 to 17 & 1996 & 404 & $\begin{array}{l}\text { mean } \\
\text { std. }\end{array}$ & $\begin{array}{c}0.73 \\
(9.5565)\end{array}$ & $\begin{array}{c}7.57 \\
(76.9312)\end{array}$ & $\begin{array}{c}2.45 \\
(77.2715)\end{array}$ & $\begin{array}{c}0.073 \\
(5.6043)\end{array}$ \\
\hline \multirow{2}{*}{ Bolivia } & 10 to 14 & 1997 & 3455 & $\begin{array}{l}\text { mean } \\
\text { std. }\end{array}$ & $\begin{array}{c}0.95 \\
(4.7711)\end{array}$ & $\begin{array}{c}4.68 \\
(40.8541)\end{array}$ & $\begin{array}{c}1.25 \\
(33.2223)\end{array}$ & $\begin{array}{c}0.145 \\
(7.5443)\end{array}$ \\
\hline & 15 to 17 & 1997 & 1745 & $\begin{array}{l}\text { mean } \\
\text { std. }\end{array}$ & $\begin{array}{c}0.80 \\
(8.6462)\end{array}$ & $\begin{array}{c}7.92 \\
(52.5978)\end{array}$ & $\begin{array}{c}2.00 \\
(50.6836)\end{array}$ & $\begin{array}{c}0.300 \\
(9.8805)\end{array}$ \\
\hline \multirow{2}{*}{ Brasil } & 10 to 14 & 1996 & 26058 & $\begin{array}{l}\text { mean } \\
\text { std. }\end{array}$ & $\begin{array}{c}0.92 \\
(5.8065)\end{array}$ & $\begin{array}{c}3.39 \\
(42.3508)\end{array}$ & $\begin{array}{c}2.63 \\
(38.5367)\end{array}$ & $\begin{array}{c}0.133 \\
(7.2904)\end{array}$ \\
\hline & 15 to 17 & 1996 & 14038 & $\begin{array}{l}\text { mean } \\
\text { std. }\end{array}$ & $\begin{array}{c}0.75 \\
(9.3261)\end{array}$ & $\begin{array}{c}5.81 \\
(58.5171)\end{array}$ & $\begin{array}{c}4.14 \\
(58.5079)\end{array}$ & $\begin{array}{c}0.376 \\
(10.3790)\end{array}$ \\
\hline \multirow{2}{*}{ Chile } & 10 to 14 & 1996 & 5383 & $\begin{array}{l}\text { mean } \\
\text { std. }\end{array}$ & $\begin{array}{c}0.98 \\
(3.0579)\end{array}$ & $\begin{array}{c}5.94 \\
(29.5208)\end{array}$ & $\begin{array}{c}1.04 \\
(24.8330)\end{array}$ & $\begin{array}{c}0.009 \\
(2.0487)\end{array}$ \\
\hline & 15 to 17 & 1996 & 5191 & $\begin{array}{l}\text { mean } \\
\text { std. }\end{array}$ & $\begin{array}{c}0.87 \\
(7.2543)\end{array}$ & $\begin{array}{c}8.58 \\
(37.2997)\end{array}$ & $\begin{array}{c}1.38 \\
(34.2772)\end{array}$ & $\begin{array}{c}0.053 \\
(4.8417)\end{array}$ \\
\hline \multirow{2}{*}{ Colombia } & 10 to 14 & 1997 & 11618 & $\begin{array}{l}\text { mean } \\
\text { std. }\end{array}$ & $\begin{array}{c}0.87 \\
(7.1788)\end{array}$ & $\begin{array}{c}5.21 \\
(42.5296)\end{array}$ & $\begin{array}{c}1.76 \\
(40.3917)\end{array}$ & $\begin{array}{c}0.079 \\
(5.7948)\end{array}$ \\
\hline & 15 to 17 & 1997 & 10900 & $\begin{array}{l}\text { mean } \\
\text { std. }\end{array}$ & $\begin{array}{c}0.74 \\
(9.4080)\end{array}$ & $\begin{array}{c}7.25 \\
(53.2525)\end{array}$ & $\begin{array}{c}2.73 \\
(52.9242)\end{array}$ & $\begin{array}{c}0.193 \\
(8.4419)\end{array}$ \\
\hline \multirow{2}{*}{ Costa Rica } & 10 to 14 & 1996 & 1775 & $\begin{array}{c}\text { mean } \\
\text { std. }\end{array}$ & $\begin{array}{c}0.82 \\
(8.0688)\end{array}$ & $\begin{array}{c}5.50 \\
(31.0810)\end{array}$ & $\begin{array}{c}1.49 \\
(28.4245)\end{array}$ & $\begin{array}{c}0.075 \\
(5.5858)\end{array}$ \\
\hline & 15 to 17 & 1996 & 1633 & $\begin{array}{l}\text { mean } \\
\text { std. }\end{array}$ & $\begin{array}{c}0.63 \\
(10.4827)\end{array}$ & $\begin{array}{c}7.34 \\
(60.0665)\end{array}$ & $\begin{array}{c}2.63 \\
(60.2660)\end{array}$ & $\begin{array}{c}0.226 \\
(9.0776)\end{array}$ \\
\hline \multirow{2}{*}{ Ecuador } & 10 to 14 & 1996 & 2889 & $\begin{array}{l}\text { mean } \\
\text { std. }\end{array}$ & $\begin{array}{c}0.95 \\
(4.6660)\end{array}$ & $\begin{array}{c}5.58 \\
(39.5694)\end{array}$ & $\begin{array}{c}0.43 \\
(29.0043)\end{array}$ & $\begin{array}{c}0.036 \\
(3.9828)\end{array}$ \\
\hline & 15 to 17 & 1996 & 1712 & $\begin{array}{l}\text { mean } \\
\text { std. }\end{array}$ & $\begin{array}{c}0.81 \\
(8.5101)\end{array}$ & $\begin{array}{c}8.70 \\
(45.6919)\end{array}$ & $\begin{array}{c}1.29 \\
(44.2900)\end{array}$ & $\begin{array}{c}0.148 \\
(7.6637)\end{array}$ \\
\hline \multirow{2}{*}{ Mexico } & 10 to 14 & 1996 & 3890 & $\begin{array}{l}\text { mean } \\
\text { std. }\end{array}$ & $\begin{array}{c}0.85 \\
(7.6021)\end{array}$ & $\begin{array}{c}6.02 \\
(38.3625)\end{array}$ & $\begin{array}{c}0.96 \\
(36.1511)\end{array}$ & $\begin{array}{c}0.117 \\
(6.8663)\end{array}$ \\
\hline & 15 to 17 & 1996 & 3430 & $\begin{array}{l}\text { mean } \\
\text { std. }\end{array}$ & $\begin{array}{c}0.56 \\
(10.7301)\end{array}$ & $\begin{array}{c}8.09 \\
(57.5886)\end{array}$ & $\begin{array}{c}1.89 \\
(57.3361)\end{array}$ & $\begin{array}{c}0.287 \\
(9.7676)\end{array}$ \\
\hline \multirow{2}{*}{ Panama } & 10 to 14 & 1997 & 2436 & $\begin{array}{l}\text { mean } \\
\text { std. }\end{array}$ & $\begin{array}{c}0.95 \\
(4.7310)\end{array}$ & $\begin{array}{c}5.21 \\
(38.7609)\end{array}$ & $\begin{array}{c}0.73 \\
(27.9204)\end{array}$ & $\begin{array}{c}0.006 \\
(1.5999)\end{array}$ \\
\hline & 15 to 17 & 1997 & 1205 & $\begin{array}{l}\text { mean } \\
\text { std. }\end{array}$ & $\begin{array}{c}0.77 \\
(9.0508)\end{array}$ & $\begin{array}{c}8.40 \\
(44.9661)\end{array}$ & $\begin{array}{c}1.58 \\
(44.4404)\end{array}$ & $\begin{array}{c}0.059 \\
(5.0785)\end{array}$ \\
\hline \multirow{2}{*}{ Paraguay } & 10 to 14 & 1998 & 1626 & $\begin{array}{l}\text { mean } \\
\text { std. }\end{array}$ & $\begin{array}{c}0.92 \\
(5.9661)\end{array}$ & $\begin{array}{c}4.53 \\
(39.0006)\end{array}$ & $\begin{array}{c}1.42 \\
(31.2237)\end{array}$ & $\begin{array}{c}0.141 \\
(7.5016)\end{array}$ \\
\hline & 15 to 17 & 1998 & 736 & $\begin{array}{l}\text { mean } \\
\text { std. }\end{array}$ & $\begin{array}{c}0.68 \\
(9.9166)\end{array}$ & $\begin{array}{c}7.56 \\
(45.6245)\end{array}$ & $\begin{array}{c}2.34 \\
(45.1430)\end{array}$ & $\begin{array}{c}0.349 \\
(10.1110)\end{array}$ \\
\hline \multirow{2}{*}{ Peru } & 10 to 14 & 1997 & 1742 & $\begin{array}{l}\text { mean } \\
\text { std. }\end{array}$ & $\begin{array}{c}0.96 \\
(4.1737)\end{array}$ & $\begin{array}{c}5.17 \\
(37.6268)\end{array}$ & $\begin{array}{c}0.78 \\
(30.4442)\end{array}$ & $\begin{array}{c}0.193 \\
(8.4161)\end{array}$ \\
\hline & 15 to 17 & 1997 & 907 & $\begin{array}{l}\text { mean } \\
\text { std. }\end{array}$ & $\begin{array}{c}0.78 \\
(8.9836)\end{array}$ & $\begin{array}{c}8.37 \\
(43.4302)\end{array}$ & $\begin{array}{c}1.62 \\
(41.0304)\end{array}$ & $\begin{array}{c}0.326 \\
(10.1674)\end{array}$ \\
\hline \multirow{2}{*}{ Venezuela } & 10 to 14 & 1996 & 5601 & $\begin{array}{l}\text { mean } \\
\text { std. }\end{array}$ & $\begin{array}{c}0.95 \\
(4.5763)\end{array}$ & $\begin{array}{c}5.29 \\
(49.1237)\end{array}$ & $\begin{array}{c}0.69 \\
(43.4931)\end{array}$ & $\begin{array}{c}0.041 \\
(4.2511)\end{array}$ \\
\hline & 15 to 17 & 1996 & 3164 & $\begin{array}{l}\text { mean } \\
\text { std. }\end{array}$ & $\begin{array}{c}0.72 \\
(9.5740)\end{array}$ & $\begin{array}{c}8.13 \\
(70.0534)\end{array}$ & $\begin{array}{c}1.84 \\
(69.3865)\end{array}$ & $\begin{array}{c}0.177 \\
(8.1760)\end{array}$ \\
\hline
\end{tabular}


Table 2: Effect of Employment on School Attendance

\begin{tabular}{ccccc}
\hline \multirow{2}{*}{ Variable } & \multicolumn{4}{c}{ School Attendance } \\
& boys & girls & boys $15-17$ & girls \\
\hline Child Employed & -0.9235 & -0.5395 & -1.1323 & -0.7279 \\
& $(0.0012)$ & $(0.0018)$ & $(0.0010)$ & $(0.0013)$ \\
Age (Deviation) & -0.1125 & -0.1751 & -0.203 & -0.2007 \\
& $(0.0005)$ & $(0.0005)$ & $(0.0006)$ & $(0.0006)$ \\
Age Squared & -0.0664 & -0.0415 & -0.0151 & -0.0337 \\
& $(0.0003)$ & $(0.0003)$ & $(0.0010)$ & $(0.0011)$ \\
Family Income (Deviation) & 0.0806 & 0.0983 & 0.104 & 0.1324 \\
Family Income Squared & $(0.0006)$ & $(0.0007)$ & $(0.0006)$ & $(0.0006)$ \\
& 0.0033 & 0.0043 & 0.0047 & 0.0061 \\
Father's Education (Log) & $(0.0001)$ & $(0.0001)$ & $(0.0000)$ & $(0.0000)$ \\
Father's Education Squared & 0.1355 & 0.0422 & -0.0538 & 0.015 \\
& $(0.0020)$ & $(0.0021)$ & $(0.0018)$ & $(0.0020)$ \\
Mother's Education (Log) & 0.0279 & 0.0933 & 0.1213 & 0.1102 \\
& $(0.0009)$ & $(0.0010)$ & $(0.0007)$ & $(0.0009)$ \\
Mother's Education Squared & 0.1429 & 0.1196 & -0.0759 & 0.0771 \\
& $(0.0021)$ & $(0.0022)$ & $(0.0019)$ & $(0.0021)$ \\
& 0.0673 & 0.0863 & 0.1589 & 0.0942 \\
Urban & $(0.0010)$ & $(0.0011)$ & $(0.0008)$ & $(0.0009)$ \\
& 0.0757 & 0.2212 & 0.0189 & 0.1976 \\
& $(0.0012)$ & $(0.0012)$ & $(0.0011)$ & $(0.0011)$ \\
\hline
\end{tabular}

* Country fixed effects present but not reported

Table 3: Effect of Employment on Education Gap

\begin{tabular}{ccccc}
\hline \multirow{2}{*}{ Variable } & \multicolumn{2}{c}{ age $10-14$} & \multicolumn{2}{c}{ age 15-17 } \\
& boys & girls & boys & girls \\
\hline Child Employed & 0.320333 & 0.199664 & 0.854832 & 0.2732 \\
& $(0.0248)$ & $(0.0365)$ & $(0.0323)$ & $(0.0438)$ \\
Age (Deviation) & 0.269013 & 0.225805 & 0.386152 & 0.336487 \\
& $(0.0064)$ & $(0.0067)$ & $(0.0165)$ & $(0.0180)$ \\
Age Squared & -0.003221 & 0.008324 & 0.016552 & -0.00547 \\
& $(0.0047)$ & $(0.0049)$ & $(0.0283)$ & $(0.0306)$ \\
Family Income (Deviation) & -0.233122 & -0.184824 & -0.314436 & -0.246391 \\
Family Income Squared & $(0.0094)$ & $(0.0099)$ & $(0.0160)$ & $(0.0178)$ \\
& -0.012348 & -0.008627 & -0.015436 & -0.012836 \\
Father's Education (Log) & $(0.0009)$ & $(0.0012)$ & $(0.0012)$ & $(0.0015)$ \\
Father's Education Squared & -0.749893 & -0.64685 & -0.898548 & -0.8042 \\
Mother's Education (Log) & $(0.0308)$ & $(0.0323)$ & $(0.0527)$ & $(0.0595)$ \\
& 0.137782 & 0.099897 & 0.117253 & 0.06507 \\
Mother's Education Squared & $(0.0117)$ & $(0.0124)$ & $(0.0202)$ & $(0.0225)$ \\
& -0.568491 & -0.553266 & -0.872727 & -0.604391 \\
Urban & $(0.0318)$ & $(0.0340)$ & $(0.0560)$ & $(0.0617)$ \\
& $(0.024021$ & 0.030789 & 0.067654 & -0.052791 \\
& -0.183883 & $(0.0135)$ & $(0.0222)$ & $(0.0241)$ \\
& $(0.0189)$ & -0.261566 & -0.344605 & -0.580305 \\
\end{tabular}

* Country fixed effects present but not reported 
Table 4(a): Child Employment Regressions: Variable Estimates

\begin{tabular}{ccccc}
\hline \multirow{2}{*}{ Variable } & \multicolumn{2}{c}{ Ages 10-14 } & \multicolumn{2}{c}{ Ages 15-17 } \\
& Boys & Girls & Boys & Girls \\
\hline & 0.2194 & 0.1817 & 0.2225 & 0.1683 \\
Age (Deviation) & $(0.0004)$ & $(0.0005)$ & $(0.0005)$ & $(0.0007)$ \\
& 0.0149 & 0.0031 & -0.0326 & -0.0051 \\
Age Squared & $(0.0003)$ & $(0.0004)$ & $(0.0009)$ & $(0.0011)$ \\
Family Income & -0.1242 & -0.0465 & -0.0527 & 0.0124 \\
(Deviation) & $(0.0006)$ & $(0.0007)$ & $(0.0005)$ & $(0.0007)$ \\
Family Income Squared & -0.0003 & 0.0033 & 0.0035 & 0.0061 \\
Father's Education & $(0.0001)$ & $(0.0001)$ & $(0.0001)$ & $(0.0001)$ \\
(Log) & -0.0619 & 0.0550 & 0.0527 & 0.1169 \\
Father's Education & $(0.0017)$ & $(0.0023)$ & $(0.0017)$ & $(0.0021)$ \\
Squared & -0.0626 & -0.0476 & -0.1222 & -0.1017 \\
Mother's Education & $(0.0008)$ & $(0.0010)$ & $(0.0007)$ & $(0.0009)$ \\
(Log) & 0.0990 & -0.0915 & 0.0694 & 0.0572 \\
Mother's Education & $(0.0018)$ & $(0.0023)$ & $(0.0018)$ & $(0.0022)$ \\
Squared & -0.1246 & -0.0298 & -0.1547 & -0.1093 \\
Urban & $(0.0008)$ & $(0.0011)$ & $(0.0008)$ & $(0.0009)$ \\
& -0.6633 & -0.5986 & -0.3831 & -0.2898 \\
& $(0.0010)$ & $(0.0014)$ & $(0.0010)$ & $(0.0013)$ \\
\hline
\end{tabular}

*SOURCE: Author's calculations from household survey data

Table 4(b): Child Employment Regressions:Country-Effect Estimates

\begin{tabular}{ccccc}
\hline \multirow{2}{*}{ Ages 10-14 } & \multicolumn{2}{c}{ Amployment } & \multicolumn{2}{c}{ Ages 15-17 } \\
& Boys & Girls & Boys & Girls \\
\hline \multirow{3}{*}{ Argentina } & -3.0987 & -3.0488 & -1.9231 & -2.4105 \\
& $(0.0123)$ & $(0.0189)$ & $(0.0115)$ & $(0.0124)$ \\
Bolivia & -0.4114 & -0.6593 & 0.3114 & -0.1116 \\
& $(0.0023)$ & $(0.0027)$ & $(0.0026)$ & $(0.0029)$ \\
Brasil & -0.2569 & -0.8997 & 0.7301 & -0.2156 \\
& $(0.0013)$ & $(0.0017)$ & $(0.0015)$ & $(0.0017)$ \\
Chile & -1.5227 & -1.8492 & -0.3211 & -1.1953 \\
& $(0.0038)$ & $(0.0045)$ & $(0.0023)$ & $(0.0030)$ \\
Colombia & -0.8531 & -1.5948 & 0.1520 & -0.9668 \\
& $(0.0016)$ & $(0.0022)$ & $(0.0016)$ & $(0.0020)$ \\
Costa Rica & -0.6790 & -1.5533 & 0.5251 & -0.7966 \\
& $(0.0031)$ & $(0.0045)$ & $(0.0026)$ & $(0.0035)$ \\
Ecuador & -0.4984 & -1.1501 & 0.3800 & -0.7160 \\
& $(0.0032)$ & $(0.0043)$ & $(0.0028)$ & $(0.0038)$ \\
Mexico & -0.5547 & -1.2819 & 0.4089 & -0.4751 \\
& $(0.0020)$ & $(0.0026)$ & $(0.0019)$ & $(0.0022)$ \\
Panama & -1.1353 & -1.5623 & -0.0900 & -0.9313 \\
& $(0.0066)$ & $(0.0080)$ & $(0.0041)$ & $(0.0054)$ \\
Paraguay & -0.2140 & -1.0005 & 0.8168 & -0.3545 \\
& $(0.0027)$ & $(0.0036)$ & $(0.0035)$ & $(0.0040)$ \\
Peru & -0.0928 & -0.4374 & 0.5531 & 0.0157 \\
& $(0.0029)$ & $(0.0032)$ & $(0.0033)$ & $(0.0035)$ \\
Venezuela & -0.1478 & -1.6480 & 0.6032 & -0.8639 \\
& $(0.0024)$ & $(0.0050)$ & $(0.0023)$ & $(0.0032)$ \\
\hline & & & &
\end{tabular}

*SOURCE: Author's calculations from household survey data 
Table 5: Correlation of Country Effects with GDP and Ratification of ILO Convention C-138

\begin{tabular}{lcccc}
\hline & \multicolumn{2}{c}{ Boys } & \multicolumn{2}{c}{ Girls } \\
& Employment & Hours & Employment & Hours \\
\hline \multicolumn{5}{c}{ Ages $10-14$} \\
Log(GDP) & -0.82191 & -3.31319 & -1.04828 & -2.653 \\
StdErr & 0.44032 & $(2.813)$ & $(0.316)$ & $(1.247)$ \\
tValue & -1.87 & -1.18 & -3.32 & -2.13 \\
Prob(t;H0) & 0.0915 & 0.2662 & 0.0078 & 0.0593 \\
R-squared & 0.2584 & 0.12182 & 0.5237 & 0.3116 \\
Corr(FX,RATIFY) & -0.31828 & -0.35107 & -0.3799 & -0.32649 \\
& \multicolumn{5}{c}{ Ages $15-17$} \\
Log(GDP) & -0.62573 & -5.79313 & -0.87974 & -6.171 \\
StdErr & 0.39724 & $(4.685)$ & $(0.309)$ & $(3.214)$ \\
tValue & -1.58 & -1.24 & -2.84 & -1.92 \\
Prob(t;H0) & 0.1463 & 0.2446 & 0.0174 & 0.0838 \\
R-squared & 0.1988 & 0.1326 & 0.4471 & 0.2693 \\
Corr(FX,RATIFY) & -0.33639 & -0.34182 & -0.38383 & -0.37999 \\
\hline SOURCE: Author's calculations using estimated country effects in Table 2 and GDP from \\
Table 3.
\end{tabular}


Table A1 Child Labor-Force Participation and Real GDP

\begin{tabular}{|c|c|c|c|c|c|}
\hline Country & $\begin{array}{l}\text { Real GDP } \\
\text { per capita }\end{array}$ & $\begin{array}{l}\text { Percent of } \\
\text { Children } \\
\text { Working }\end{array}$ & Country & $\begin{array}{l}\text { Real GDP } \\
\text { per capita }\end{array}$ & $\begin{array}{l}\text { Percent of } \\
\text { Children } \\
\text { Working }\end{array}$ \\
\hline Algeria & 1097 & 1 & Mauritius & 3688 & 23 \\
\hline Argentina & 9070 & 4 & Mexico & 4265 & 6 \\
\hline Bangladesh & 286 & 29 & Morocco & 1246 & 4 \\
\hline Botswana & 3209 & 16 & Mozambique & 94 & 33 \\
\hline Brasil & 4930 & 15 & Myanmar & 274 & 24 \\
\hline Burkina Faso & 160 & 48 & Namibia & 2046 & 20 \\
\hline Burundi & 126 & 49 & Nepal & 217 & 44 \\
\hline Cambodia & 159 & 24 & Nicaragua & 431 & 13 \\
\hline Chad & 149 & 38 & Niger & 191 & 45 \\
\hline China & 745 & 10 & Nigeria & 1376 & 25 \\
\hline Colombia & 2384 & 6 & Pakistan & 466 & 17 \\
\hline Congo & 702 & 29 & Panama & 3159 & 3 \\
\hline Costa Rica & 2540 & 5 & Paraguay & 1961 & 7 \\
\hline Côte d'Ivoire & 731 & 20 & Peru & 2674 & 2 \\
\hline Dominican Republic & 1841 & 15 & Philippines & 1151 & 7 \\
\hline Ecuador & 1648 & 5 & Portugal & 10269 & 2 \\
\hline Egypt & 1168 & 10 & Rwanda & 170 & 42 \\
\hline El Salvador & 1935 & 15 & Senegal & 519 & 30 \\
\hline Ethiopia & 104 & 42 & Sierra Leone & 260 & 15 \\
\hline Guatemala & 1691 & 15 & Sri Lanka & 826 & 2 \\
\hline Guinea & 535 & 33 & Thailand & 2576 & 15 \\
\hline Haiti & 398 & 24 & Togo & 327 & 28 \\
\hline Honduras & 785 & 8 & Ukraine & 973 & 22 \\
\hline India & 402 & 13 & Uruguay & 6026 & 2 \\
\hline Indonesia & 1055 & 9 & Venezuela & 3678 & 1 \\
\hline Iran (Islamic Rep. & 2466 & 4 & Viet Nam & 330 & 8 \\
\hline Kenya & 356 & 40 & Yemen & 318 & 20 \\
\hline Malaysia & 4665 & & Zimbabwe & 802 & 28 \\
\hline
\end{tabular}

Source: United Nations Human Development Report, 2000 
Table A2: Survey Instruments and Sample Sizes

\begin{tabular}{cccl}
\hline Country & Year & Sample Size* & \multicolumn{1}{c}{ Name of Survey Instrument } \\
\hline Argentina & 1996 & 1093 & Encuesta Permanente de Hogares \\
Bolivia & 1997 & 5200 & Encuesta National de Empleo \\
Brasil & 1996 & 40096 & Pesquisa Nacional por Amostra de Domicilios \\
Chile & 1996 & 10574 & Encuesta de Charaterizacion SocioEconomica Nacional \\
Colombia & 1997 & 22518 & Encuesta Nacional de Hogares--Fuerza de Trabajo \\
Costa Rica & 1996 & 3408 & Encuesta Permanente de Hogares de Propositos Multiples \\
Ecuador & 1996 & 4601 & Encuesta Periodica de Empleo y desempleo en el Area Urbano \\
Mexico & 1995 & 7320 & Encuesta Nacional De Ingreso Gasto de los Hogares \\
Panama & 1997 & 3641 & Encuesta de Hogares \\
Paraguay & 1998 & 2362 & Encuesta Integrada de Hogares \\
Peru & 1997 & 2649 & Encuesta Nacional de Hogares \\
Venezuela & 1995 & 8765 & Encuesta de Hogares por Mustreo \\
\hline Total & & 112227 &
\end{tabular}

Table A3: Aggregate Variables by Country

\begin{tabular}{ccccccc}
\hline Country & $\begin{array}{c}\text { GDP per } \\
\text { capita }\end{array}$ & $\begin{array}{c}\text { Gini } \\
\text { Coefficient for } \\
\text { Income* }\end{array}$ & $\begin{array}{c}\text { Mincer } \\
\text { Coefficient }\end{array}$ & $\begin{array}{c}\text { Agri- } \\
\text { culture's } \\
\text { Share of } \\
\text { GDP }\end{array}$ & $\begin{array}{c}\text { Total } \\
\text { Fertility } \\
\text { Rate }\end{array}$ & $\begin{array}{c}\text { Ratified } \\
\text { C138? }\end{array}$ \\
\hline Argentina & 10300 & 47.02 & 0.11 & 7.00 & 2.60 & 1996 \\
Bolivia & 2880 & 58.77 & 0.07 & 16.00 & 4.40 & 1997 \\
Brasil & 6480 & 59.06 & 0.15 & 8.00 & 2.30 & No \\
Chile & 12730 & 56.38 & 0.12 & 7.00 & 2.40 & 1999 \\
Colombia & 6810 & 56.70 & 0.15 & 11.00 & 2.80 & No \\
Costa Rica & 6650 & 45.89 & 0.11 & 15.00 & 2.80 & 1976 \\
Ecuador & 4940 & 56.00 & 0.10 & 12.00 & 3.10 & No \\
Mexico & 8370 & 52.76 & 0.14 & 5.00 & 2.80 & No \\
Panama & 7168 & 57.55 & 0.13 & 8.00 & 2.60 & No \\
Paraguay & 3980 & 62.03 & 0.10 & 23.00 & 4.20 & No \\
Peru & 4680 & 50.50 & 0.09 & 7.00 & 3.00 & No \\
Venezuela & 9200 & 49.63 & 0.08 & 4.00 & 3.00 & 1987 \\
\hline
\end{tabular}

Source: GDP, fertility and Agriculture Percent from World Bank Development Indicators CD; Income Ginis from Szekely and Hilgert (1999). Mincer coefficients from Bils and Klenow (1999) 
Table A4: Robustness tests for Employment Fixed Effects

Fixed Effect Variable Estimate StdErr tValue

\begin{tabular}{|c|c|c|c|c|c|c|}
\hline \multirow[t]{2}{*}{ 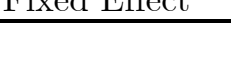 } & & & & & & \multirow{3}{*}{0.21111} \\
\hline & Gini & -0.56992 & $(3.5974)$ & -0.16 & 0.8776 & \\
\hline \multirow{7}{*}{$\begin{array}{c}\text { Employment, } \\
\text { Boys 10-14 }\end{array}$} & $\log \mathrm{GDP}$ & -0.63668 & $(0.4332)$ & -1.47 & 0.1757 & \\
\hline & AgriPct & -0.0415 & $(0.0376)$ & -1.1 & 0.2985 & \multirow{2}{*}{0.30316} \\
\hline & $\log \mathrm{GDP}$ & -1.01346 & $(0.5216)$ & -1.94 & 0.0839 & \\
\hline & TotFert & -0.17763 & $(0.3597)$ & -0.49 & 0.6333 & \multirow{2}{*}{0.22978} \\
\hline & $\log \mathrm{GDP}$ & -0.8476 & $(0.6218)$ & -1.36 & 0.206 & \\
\hline & Mincer & 0.66751 & $(5.8643)$ & 0.11 & 0.9119 & \multirow{2}{*}{0.21005} \\
\hline & $\log \mathrm{GDP}$ & -0.63134 & $(0.4438)$ & -1.42 & 0.1886 & \\
\hline \multirow{8}{*}{$\begin{array}{c}\text { Employment, } \\
\text { Girls 10-14 }\end{array}$} & Gini & 0.59968 & $(2.7557)$ & 0.22 & 0.8326 & 0.52779 \\
\hline & $\log \mathrm{GDP}$ & -0.90053 & $(0.3147)$ & -2.86 & 0.0187 & 0.52779 \\
\hline & AgriPct & -0.05177 & $(0.0248)$ & -2.09 & 0.0666 & \multirow{2}{*}{0.68} \\
\hline & $\log \mathrm{GDP}$ & -1.40005 & $(0.3312)$ & -4.23 & 0.0022 & \\
\hline & TotFert & -0.41445 & $(0.2425)$ & -1.71 & 0.1216 & \multirow{2}{*}{0.64161} \\
\hline & $\log \mathrm{GDP}$ & -1.506 & $(0.4246)$ & -3.55 & 0.0062 & \\
\hline & Mincer & 3.33591 & $(4.5605)$ & 0.73 & 0.4831 & \multirow{2}{*}{0.55195} \\
\hline & $\log \mathrm{GDP}$ & -1.06067 & $(0.3395)$ & -3.12 & 0.0122 & \\
\hline \multirow{8}{*}{$\begin{array}{c}\text { Employment, } \\
\text { Boys 15-17 }\end{array}$} & Gini & -0.3643 & $(3.2071)$ & -0.11 & 0.9121 & \multirow{2}{*}{0.17492} \\
\hline & $\log \mathrm{GDP}$ & -0.50074 & $(0.3765)$ & -1.33 & 0.2163 & \\
\hline & AgriPct & -0.01553 & $(0.0377)$ & -0.41 & 0.6902 & \multirow{2}{*}{0.18901} \\
\hline & $\log \mathrm{GDP}$ & -0.62433 & $(0.4854)$ & -1.29 & 0.2304 & \\
\hline & TotFert & -0.21389 & $(0.3395)$ & -0.63 & 0.5443 & \multirow{2}{*}{0.20864} \\
\hline & $\log \mathrm{GDP}$ & -0.74978 & $(0.5431)$ & -1.38 & 0.2007 & \\
\hline & Mincer & 3.00161 & $(5.3251)$ & 0.56 & 0.5867 & \multirow{2}{*}{0.20191} \\
\hline & $\log \mathrm{GDP}$ & -0.57543 & $(0.3818)$ & -1.51 & 0.166 & \\
\hline \multirow{8}{*}{$\begin{array}{c}\text { Employment, } \\
\text { Girls 15-17 }\end{array}$} & Gini & 0.82562 & $(2.7322)$ & 0.3 & 0.7694 & 0.44256 \\
\hline & $\log \mathrm{GDP}$ & -0.74444 & $(0.3142)$ & -2.37 & 0.042 & 0.44256 \\
\hline & AgriPct & -0.04618 & $(0.0278)$ & -1.66 & 0.1304 & \multirow{2}{*}{0.56943} \\
\hline & $\log G D P$ & -1.1901 & $(0.3571)$ & -3.33 & 0.0088 & \\
\hline & TotFert & -0.30752 & $(0.2718)$ & -1.13 & 0.2872 & \multirow{2}{*}{0.50701} \\
\hline & $\log \mathrm{GDP}$ & -1.1708 & $(0.4429)$ & -2.64 & 0.0268 & \\
\hline & Mincer & 3.94385 & $(4.4431)$ & 0.89 & 0.3978 & \multirow{2}{*}{0.48223} \\
\hline & $\log \mathrm{GDP}$ & -0.90722 & $(0.3175)$ & -2.86 & 0.0189 & \\
\hline
\end{tabular}


Table A5: Impact of Estimated Chile Effect on Child Employment

\begin{tabular}{|c|c|c|c|c|c|}
\hline \multirow{3}{*}{ Variable } & \multirow{3}{*}{ Mean } & \multicolumn{4}{|c|}{ Employment } \\
\hline & & \multicolumn{2}{|c|}{ Ages 10-14 } & \multicolumn{2}{|c|}{ Ages 15-17 } \\
\hline & & Boys & Girls & Boys & Girls \\
\hline \multirow{2}{*}{ Argentina } & Actual & 0.0168 & 0.0057 & 0.1079 & 0.0356 \\
\hline & Chile Effect & 0.2912 & 0.1345 & 0.6422 & 0.2777 \\
\hline \multirow{2}{*}{ Bolivia } & Actual & 0.156 & 0.1333 & 0.3325 & 0.2654 \\
\hline & Chile Effect & 0.0169 & 0.0107 & 0.1433 & 0.0436 \\
\hline \multirow{2}{*}{ Brasil } & Actual & 0.1837 & 0.08 & 0.4842 & 0.2489 \\
\hline & Chile Effect & 0.0151 & 0.0093 & 0.1377 & 0.0487 \\
\hline Chile & Actual & 0.0114 & 0.0071 & 0.0767 & 0.0285 \\
\hline \multirow{2}{*}{ Colombia } & Actual & 0.1218 & 0.0324 & 0.2944 & 0.0835 \\
\hline & Chile Effect & 0.0332 & 0.0178 & 0.1553 & 0.0537 \\
\hline \multirow{2}{*}{ Costa Rica } & Actual & 0.1157 & 0.0319 & 0.3409 & 0.0939 \\
\hline & Chile Effect & 0.0206 & 0.0158 & 0.1045 & 0.0431 \\
\hline \multirow{2}{*}{ Ecuador } & Actual & 0.0483 & 0.022 & 0.2153 & 0.071 \\
\hline & Chile Effect & 0.0036 & 0.0033 & 0.0682 & 0.0257 \\
\hline \multirow{2}{*}{ Mexico } & Actual & 0.1726 & 0.061 & 0.3743 & 0.1885 \\
\hline & Chile Effect & 0.0279 & 0.0173 & 0.1467 & 0.0544 \\
\hline \multirow{2}{*}{ Panama } & Actual & 0.0068 & 0.0043 & 0.0805 & 0.0338 \\
\hline & Chile Effect & 0.0022 & 0.0018 & 0.0512 & 0.0182 \\
\hline \multirow{2}{*}{ Paraguay } & Actual & 0.202 & 0.0733 & 0.4891 & 0.2019 \\
\hline & Chile Effect & 0.016 & 0.0107 & 0.1219 & 0.0469 \\
\hline \multirow{2}{*}{ Peru } & Actual & 0.2153 & 0.1699 & 0.3708 & 0.283 \\
\hline & Chile Effect & 0.0133 & 0.009 & 0.1143 & 0.0371 \\
\hline \multirow{2}{*}{ Venezuela } & Actual & 0.0751 & 0.005 & 0.2911 & 0.0565 \\
\hline & Chile Effect & 0.0025 & 0.0027 & 0.0702 & 0.0277 \\
\hline \multirow{2}{*}{$\begin{array}{l}\text { Cross-Country } \\
\text { Mean }\end{array}$} & Actual & 0.1105 & 0.0522 & 0.2881 & 0.1325 \\
\hline & Chile Effect & 0.0378 & 0.02 & 0.1527 & 0.0588 \\
\hline
\end{tabular}

Author's compuations based on fixed effects estimated in Table 4 (b) 
Table A6: School Attendance Regressions:Country-Effect Estimates

\begin{tabular}{ccccc}
\hline \multirow{2}{*}{ Variable } & \multicolumn{3}{c}{ Ages 10-14 } & \multicolumn{2}{c}{ Ages 15-17 } \\
& Boys & Girls & Boys & Girls \\
\hline \multirow{3}{*}{ Argentina } & 1.7203 & 1.9110 & 0.6144 & 0.6322 \\
& $(0.0102)$ & $(0.0152)$ & $(0.0078)$ & $(0.0093)$ \\
Bolivia & 1.6586 & 1.2578 & 0.9692 & 0.5716 \\
& $(0.0032)$ & $(0.0032)$ & $(0.0031)$ & $(0.0032)$ \\
Brasil & 1.3505 & 1.1137 & 0.8198 & 0.4791 \\
& $(0.0016)$ & $(0.0016)$ & $(0.0017)$ & $(0.0018)$ \\
Chile & 1.4307 & 1.1708 & 0.3594 & 0.1258 \\
& $(0.0034)$ & $(0.0033)$ & $(0.0023)$ & $(0.0024)$ \\
Colombia & 0.9494 & 0.8000 & 0.4664 & 0.1864 \\
& $(0.0018)$ & $(0.0018)$ & $(0.0018)$ & $(0.0018)$ \\
Costa Rica & 0.5016 & 0.2539 & -0.0900 & -0.4760 \\
& $(0.0030)$ & $(0.0030)$ & $(0.0028)$ & $(0.0029)$ \\
Ecuador & 1.0046 & 0.7599 & 0.3561 & 0.0853 \\
& $(0.0034)$ & $(0.0036)$ & $(0.0031)$ & $(0.0034)$ \\
Mexico & 1.1149 & 0.5469 & 0.0787 & -0.5187 \\
& $(0.0023)$ & $(0.0021)$ & $(0.0021)$ & $(0.0022)$ \\
Panama & 0.8504 & 0.6022 & -0.0787 & -0.2157 \\
& $(0.0038)$ & $(0.0041)$ & $(0.0035)$ & $(0.0039)$ \\
Paraguay & 1.2524 & 0.8591 & 0.4078 & 0.0041 \\
& $(0.0036)$ & $(0.0036)$ & $(0.0038)$ & $(0.0040)$ \\
Peru & 1.7463 & 1.2111 & 0.8265 & 0.2000 \\
& $(0.0047)$ & $(0.0043)$ & $(0.0039)$ & $(0.0038)$ \\
Venezuela & 1.1661 & 0.8429 & 0.0532 & -0.1072 \\
& $(0.0029)$ & $(0.0029)$ & $(0.0025)$ & $(0.0026)$ \\
\hline
\end{tabular}

*SOURCE: Author's calculations from household survey data 
Table A7: Working Hours Regressions:Country-Effect Estimates

\begin{tabular}{|c|c|c|c|c|}
\hline \multirow{3}{*}{ Variable } & \multicolumn{4}{|c|}{ School Attendance } \\
\hline & \multicolumn{2}{|c|}{ Ages 10-14 } & \multicolumn{2}{|c|}{ Ages $15-17$} \\
\hline & Boys & Girls & Boys & Girls \\
\hline Argentina & $\begin{array}{l}-7.0198 \\
(1.4647)\end{array}$ & $\begin{array}{l}-3.6416 \\
(1.1898)\end{array}$ & $\begin{array}{c}1.7354 \\
(2.1529)\end{array}$ & $\begin{array}{c}-8.0426 \\
(1.9837)\end{array}$ \\
\hline \multirow{2}{*}{ Bolivia } & 10.3772 & 5.7960 & 25.0488 & 14.0370 \\
\hline & $(0.3250)$ & $(0.2283)$ & $(0.7373)$ & $(0.5741)$ \\
\hline \multirow{2}{*}{ Brasil } & 11.8819 & 5.0470 & 30.9324 & 14.4174 \\
\hline & $(0.1985)$ & $(0.1371)$ & $(0.4161)$ & $(0.3405)$ \\
\hline \multirow{2}{*}{ Chile } & 8.0731 & 3.0537 & 21.4773 & 8.5747 \\
\hline & $(0.2943)$ & $(0.2052)$ & $(0.5534)$ & $(0.4357)$ \\
\hline \multirow{2}{*}{ Colombia } & 9.0564 & 2.9062 & 24.6288 & 8.2708 \\
\hline & $(0.2311)$ & $(0.1589)$ & $(0.4486)$ & $(0.3658)$ \\
\hline \multirow{2}{*}{ Costa Rica } & 10.0766 & 3.3151 & 29.6469 & 10.0655 \\
\hline & $(0.4128)$ & $(0.2833)$ & $(0.7293)$ & $(0.5909)$ \\
\hline \multirow{2}{*}{ Ecuador } & 11.1348 & 4.4069 & 26.7230 & 9.9087 \\
\hline & $(0.3630)$ & $(0.2547)$ & $(0.7636)$ & $(0.6157)$ \\
\hline \multirow{2}{*}{ Mexico } & 10.8287 & 4.1263 & 28.2984 & 12.8685 \\
\hline & $(0.2994)$ & $(0.2025)$ & $(0.5564)$ & $(0.4405)$ \\
\hline \multirow{2}{*}{ Panama } & 11.2952 & 4.5525 & 22.7263 & 9.4969 \\
\hline & $(0.4036)$ & $(0.2844)$ & $(0.8922)$ & $(0.7114)$ \\
\hline \multirow{2}{*}{ Paraguay } & 12.3354 & 4.5804 & 32.6917 & 13.8887 \\
\hline & $(0.4161)$ & $(0.2907)$ & $(1.0330)$ & $(0.7966)$ \\
\hline \multirow{2}{*}{ Peru } & 11.8478 & 6.8788 & 26.4260 & 15.0512 \\
\hline & $(0.4273)$ & $(0.2902)$ & $(0.9673)$ & $(0.7218)$ \\
\hline \multirow{2}{*}{ Venezuela } & 12.5096 & 4.1085 & 28.7530 & 9.1359 \\
\hline & $(0.3088)$ & $(0.2108)$ & $(0.6516)$ & $(0.5147)$ \\
\hline
\end{tabular}

*SOURCE: Author's calculations from household survey data 